\title{
Trade Liberalization and Firm Productivity: The Case of India
}

\author{
Petia Topalova*
}

March 2007

\begin{abstract}
Using a panel of firm-level data, this paper examines the effects of India's trade reforms in the early 1990s on firm productivity in the manufacturing sector, focusing on the interaction between this policy shock and industry, firm and environment characteristics. The rapid and comprehensive tariff reductions - part of an IMF-supported adjustment program with India in 1991 — allow us to establish a causal link between inter-industry and inter-temporal variations in output tariffs, input tariffs, and effective rates of protection and consistently estimated firm productivity. Specifically, reductions in trade protectionism led to higher levels of firm productivity, with this effect strongest in industries that were import-competiting and were not subject to excessive domestic regulation. A significant productivity boost was generated by the lower tariffs on intermediate inputs as well. Interestingly, state-level characteristics, such as labor regulations, investment climate, and financial development, do not appear to influence the effect of trade liberalization on firm productivity. Finally there is strong suggestive evidence of complementarities between trade liberalization and industrial policies that encourage domestic competition.
\end{abstract}

JEL Classification Numbers: F14, O19, F13, O53.

Keywords: Trade liberalization, Tariffs, Inputs, Productivity, India.

\footnotetext{
*International Monetary Fund: PTopalova@imf.org. I would like to thank Abhijit Banerjee, Shawn Cole, David Cowen, Esther Duflo and Kalpana Kochhar for their guidance and support. This paper has greatly benefited from discussions with Irene Brambilla, Robin Burgess, Rema Hanna and Nina Pavcnik. I am also grateful to the Development lunch participants at MIT, seminar participants at the IMF Asia and Pacific Department and NEUDC for their helpful comments. The Prowess data used in this paper was provided by the Asia and Pacific Department of the International Monetary Fund while the author was a summer intern.
} 


\section{Introduction}

Over the past two decades, trade liberalization has become an important part of many countries' development strategies. ${ }^{1}$ Advocates of liberalization argue that opening up local markets to foreign competition and foreign direct investment can lead to improvements in the productivity of domestic industries, resulting in a more efficient allocation of resources and greater overall output. Critics warn that domestic firms may not be able to realize efficiency gains, because they are unable to successfully adapt foreign technologies to local methods of production or because domestic firms face binding credit constraints that prevent expansion of efficient industries as well as investments in new technology. Which of these two views is closer to the truth has important implications for trade policy: if the latter holds, benefits of liberalization may not be realized unless additional policies are devised to facilitate technology transfer or ease credit constraints.

This paper examines the effects of the recent trade liberalization in India on firm productivity using a panel of firm-level data. In particular, I address several questions: did India's sweeping trade reforms in the early 1990s lead to higher firm-level productivity? Did the potential foreign competition or access to better inputs spur the rise in productivity? How heterogeneous was the effect of liberalization across industries, firms, and economic environments? Were industries that were highly regulated at the onset of the reforms capable of realizing efficiency gains? How did firm size and ownership affect firms' response to liberalization? And finally, did institutional characteristics of the Indian states, such as financial development, investment climate, and labor laws play a role in the propagation of the trade liberalization shock?

India's experience is particularly useful in seeking to answer these questions: in 1991, in response to a severe balance of payments crisis, India turned to the International Monetary Fund for assistance in solving its external payments problem. Financial assistance from the IMF

\footnotetext{
${ }^{1}$ In a recent lecture, Anne Krueger, the First Deputy Managing Director of the International Monetary Fund, argued that liberalization is essential to growth and poverty reduction: "First, no country has achieved rapid and sustained growth in living standards without using the international economy and integrating with it. Second, countries wanting to achieve lasting reductions in poverty will be more successful the sounder are their own economic policies and the more rapid their economic growth. And third, for countries with a sound domestic policy framework, poverty reduction and growth will be more rapid the more open is the international economy and the more rapid the growth of trade in goods and services" (Heinz Arndt Memorial Lecture, August 13, 2003).
} 
included an adjustment program, requiring major structural reforms - a key one being trade liberalization. A massive overall reduction in tariffs and non-tariff barriers, as well as a reduction in the standard deviation of protection, followed. Coinciding with these tariff reductions were significant changes in firm-level productivity, as documented by Unel (2003).

A major difficulty in estimating the effects of trade liberalization on productivity is the fact that trade policies are endogenously determined: there are strong theoretical reasons to believe that countries will strategically adjust trade policies, for example by reducing tariffs only after productivity increases by local firms. This will confound estimates of the effect of liberalization on productivity. As I will argue below, because trade liberalization in India in the early 1990s was rapid, comprehensive, and externally imposed, it is reasonable to assume that the changes in level of protectionism were unrelated to firm- and industry-level productivity. Thus, the reforms initiated in 1991 and completed in the context of the export-import policy announced in the government's Eighth Plan (1992-96) comprise an excellent setting to test what effect changes in tariff protection have on firm productivity. ${ }^{2}$

In order to estimate the effect of trade liberalization on productivity, I employ an analytic framework similar to that used in Pavcnik (2002), Muendler (2004), Amiti and Konings (2005) and Fernandes (2007). First, I obtain consistent estimates of the parameters of the industry-level production functions in constructing firm level productivity measures, using the methodology of Levinsohn and Petrin (2003). Next, I examine the correlation between trade policies and manufacturing productivity in a regression framework. Following the recent work by Fernandes (2007), I allow for lagged productivity to affect the current level of productivity, an assumption made for the consistent estimation of the production function in the first stage, but generally ignored by previous studies. To limit the confounding effect of possible selective protection of industries, I focus on the pre- and immediately post-reform period, using plausibly exogenous intertemporal variation in trade protection across industries.

I find that reductions in trade protection led to higher levels of productivity. Both the increased competition, stemming from the reduction in output tariffs and the access to better inputs due to the lower input tariffs boosted productivity, with the latter effect being substantially

\footnotetext{
${ }^{2}$ India's trade policy is developed according to five-year plans. While these plans may be modified during the implementation phase, they are by and large carried out per the original draft.
} 
larger in magnitude. The productivity impact varied across industries, with import-competing industries showing a much higher responsiveness to the decline in protection. Firms in industries that were particularly burdened by regulations at the eve of the reforms did not respond to the competitive pressures with enhanced productivity, as they did not have the freedom to adjust their production technology. Firms differed in the way they responded to the trade liberalization shock. Domestic companies significantly increased productivity. However, there is no evidence that trade liberalization led to productivity improvements for foreign companies, as they were already exposed to foreign competition and learning opportunities from superior inputs. Statelevel characteristics, such as being a coastal state, labor regulations, and financial development, do not seem to influence the effect of trade liberalization on productivity. Finally, I show that the estimated effects of tariff reductions are robust to controlling for concurrent industrial policy changes, namely delicensing and relaxation of entry regulation of foreign direct investment. If anything, these concurrent reforms seem to have contributed to the productivity growth in manufacturing, though the correlations do not warrant a causal interpretation. There is also evidence of strong complementarity between trade reforms, delicensing and FDI liberalization. The efficiency gains from trade reforms were largest in industries that also experienced the most deregulation and biggest progress in FDI liberalization.

This study contributes to the literature in a few important ways. First, this is one of the first studies of the productivity impacts of trade reforms that presents direct evidence of the endogeneity of trade policies with respect to industrial productivity and accounts for it, by focusing on a narrow time window before and after the reform when movements in trade protection are plausibly exogenous. Second, it disentangles the role of import competition versus access to better and cheaper inputs for productivity improvements as in Amiti and Konings (2005), and how this role is shaped by industry, firm and environment characteristics. Finally, it provides micro evidence informing the debate on the effects of policy complementarities on economic growth.

The rest of the paper proceeds as follows. Section 2 describes the Indian reforms of 1991 focusing on trade liberalization. Section 3 outlines the empirical methodology, the data and relates the study to the existing literature. Section 4 discusses the empirical estimates of the relationship between trade reforms and productivity and section 5 concludes. 


\section{Background and the Indian Trade Liberalization}

India's post-independence development strategy was one of national self-sufficiency, and stressed the importance of government regulation of the economy. Cerra et al. (2000) characterized it as "both inward looking and highly interventionist, consisting of import protection, complex industrial licensing requirements, pervasive government intervention in financial intermediation and substantial public ownership of heavy industry." In particular, India's trade regime was amongst the most restrictive in Asia, with high nominal tariffs and extensive non-tariff barriers, including a complex import licensing system, an "actual user" policy that restricted imports by intermediaries, restrictions of certain exports and imports to the public sector ("canalization"), phased manufacturing programs that mandated progressive import substitution, and government purchase preferences for domestic producers.

It was only during the second half of the 1980s, when the focus of India's development strategy gradually shifted toward export led growth, supported by measures to promote exports and liberalize imports for exporters, that the process of liberalization began. Import and industrial licensing were eased, and tariffs replaced some quantitative restrictions, although even as late as 1989/90 a mere 12 percent of manufactured products could be imported under an open general license; still, the average tariff was one of the highest, more than 90 percent. (Cerra et al., 2000)

However, concurrent to the gradual liberalization of the late 1980s was a rise in macroeconomic imbalances - namely fiscal and balance of payments deficits - which increased India's vulnerability to shocks. The sudden increase in oil prices due to the Gulf War in 1990, the drop in remittances from Indian workers in the Middle East, and the slackened demand of important trading partners, as well as political uncertainty, undermined investor confidence and resulted in large capital outflows.

To deal with its external payments problems, the government of India requested a Stand-By Arrangement from the International Monetary Fund (IMF) in August 1991. The IMF support was conditional on an adjustment program featuring macroeconomic stabilization and structural reforms. The latter focused on the industrial and import licenses, the financial sector, the tax system, and trade policy. On trade policy, benchmarks for the first review of the StandBy Arrangement included a reduction in the level and dispersion of tariffs, and a removal of 
quantitative restrictions on imported inputs and capital goods for export production (Chopra et al., 1995). Specific policy actions in a number of areas - notably industrial deregulation, trade policy and public enterprise reforms, and some aspects of financial sector reform - also formed the basis for a World Bank Structural Adjustment Loan, as well as sector loans.

The government's export-import policy plan (1992-97) ushered in radical changes to the trade regime by sharply reducing the role of the import and export control system. The share of products subject to quantitative restrictions decreased from 87 percent in 1987/88 to 45 percent in 1994/95. The actual user condition on imports was discontinued. All 26 import licensing lists were eliminated and a "negative" list was established (Hasan et al., 2003). Thus, apart from goods in the negative list, all goods could be freely imported (subject to import tariffs) (Goldar, 2002). In addition to easing import and export restrictions, tariffs were drastically reduced (Figure 1, Panel A and B, Table A1). Average tariffs fell from more than 80 percent in 1990 to 39 percent in 1996, and the standard deviation of tariffs dropped by 50 percent during the same period. The structure of protection across industries changed (Figure 1 Panel E). Figure 1 Panel $\mathrm{F}$ shows the strikingly linear relationship between the pre-reform tariff levels and the decline in tariffs the industry experienced. This graph reflects the guidelines according to which tariff reform took place, ${ }^{3}$ namely reduction in the general level of tariffs, reduction of the spread or dispersion of tariff rates, simplification of the tariff system and rationalization of tariff rates, along with the abolition of numerous exemptions and concessions. There were some differences in the magnitude of tariff changes (and especially NTBs) according to industry use type: i.e. Consumer Durables, Consumer Nondurables, Capital goods, Intermediate and Basic goods (Figure 1, Panel C and D). Indian authorities first liberalized Basic, Intermediates and Capital goods, while Consumer Nondurables and Consumer Durables were slowly moved from the "negative" list to the list of freely importable goods only in the second half of the 1990s. The Indian Rupee was devalued 20 percent against the dollar in July 1991 and further devalued in February 1992. By 1993, India had adopted a flexible exchange rate regime (Ahluwalia, 2000).

Following the reduction in trade distortions, the ratio of total trade in manufactures to GDP rose from an average of 13 percent in the 1980s to nearly 19 percent of GDP in 1999/00 (Figure 2, Panel A). Export and import volumes also increased sharply from the early 1990s, outpacing

\footnotetext{
${ }^{3}$ The guidelines were outlined in the Chelliah report of The Tax Reform Commission constituted in 1991.
} 
growth in real output (Figure 2, Panel B).

India remained committed to further trade liberalization, and since 1997 there have been further adjustments to import tariffs. However, at the time the government announced the export-import policy in the Ninth Plan (1997-2002), sweeping reforms outlined in the previous plan had been undertaken and pressure for further reforms from external sources had abated. In particular, if policy decisions on tariff changes across industries were indeed based on expected future productivity or on industry lobbying, the empirical strategy would not be valid. Simply comparing productivity in liberalized industries to productivity in non liberalized industries would possibly give a spurious correlation between total factor productivity (TFP) growth and trade policies. As a simple check of the validity of the empirical strategy, I look for evidence that output tariffs and effective rates of protection were correlated with past industry-level performance during two periods: the period before and immediately after the crisis (1989-1996), when India's trade policy was significantly affected by externally imposed benchmarks, and the period 1997-2002, when external pressure was virtually absent. ${ }^{4}$ In the latter period, there is some evidence to suggest that trade protection measures may have been used selectively to protect less efficient industries. I discuss this in detail in the next section.

\section{Empirical Strategy, Data, and Related Literature}

The theoretical literature on trade and productivity does not provide an unambiguous prediction of the impact of trade liberalization on firm level productivity. Some argue that trade liberalization in poor economies may have a detrimental effect on growth by preventing a country's involvement in certain industries, thus potentially denying it knowledge accumulation and productivity growth (Young, 1991 and Stiglitz, 2002). Others argue the opposite: trade liberalization can actually increase overall domestic productivity through several channels. In the presence of imperfectly competitive domestic markets, trade liberalization and concurrently foreign competition can improve allocative efficiency by forcing firms to lower cost-price markups (i.e., the pro-competitive effects of trade) and thus to move them down their average cost

\footnotetext{
${ }^{4}$ Ideally, we would like to estimate the production function for the periods before 1991, 1991-1996, and after 1996, but due to the small number of observations before 1991, we combine the pre-reform and immediately post-reform period.
} 
curves, thereby effectively raising firm size and scale efficiency (i.e., scale efficiency gain of trade) (Krugman, 1979, Helpman and Krugman, 1985, Epifani, 2003). With firm heterogeneity, trade opening may also induce a reallocation of market shares towards more efficient firms and generate an aggregate productivity gain, without any productivity change at the firm level (Roberts and Tybout 1996, Melitz, 2003). Going beyond this reallocation effect of trade liberalization, Aghion et al. (2005) suggest another mechanism through which liberalization might affect productivity: the increased threat of competition raises the innovation incentives by domestic producers as they seek to deter entry by foreign competitors. The higher level of innovation leads to productivity growth at the firm level. Finally, the access to superior inputs and technology might also increase technical efficiency (Ethier, 1982, Markusen, 1989, Grossman and Helpman, 1991, Rivera-Batiz and Romer, 1991). However, other studies worry that the benefits of trade liberalization will not be realized unless complementary policies are in place (Bolaky and Freund, 2004, Hoekman and Javorcik, 2004). For example in a panel of countries, Bolaky and Freund (2004) find that trade does not stimulate growth in economies with excessive business and labor regulations, which may prevent resources from moving into the most productive sectors and to the most efficient firms, or could hinder firm's technology adoption.

Thus, whether domestic producers can take advantage of increased access to knowledge or reallocate resources towards more productive industries or firms remains questionable, especially in developing countries.

Since the theory makes ambiguous predictions, the question of whether trade liberalization leads to higher productivity remains largely empirical. In the context of developing countries, several studies have explored the relationship between firm productivity and trade reforms. Tybout et al. (1991) find no evidence of increased productivity following liberalization in Chile. Harrison (1994), Tybout and Westbrook (1995), Pavcnik (2002), Fernandes (2007) and Muendler (2004), on the other hand, do observe productivity increases following liberalization in, respectively, Côte d'Ivoire, Mexico, Chile, Colombia and Brazil. The above studies use output tariffs as a measure of trade reforms, thus estimating the productivity impacts stemming from import competition. Schor (2004) and Amiti and Konings (2005) extend this research by also looking at the effect of intermediate input tariffs in the case of Brazil and Indonesia. These studies find that, in comparison to the competition effect of trade, the access to cheaper intermediates has 
a larger impact on firm productivity.

I employ the natural experiment of the trade liberalization of India in 1991 to answer the question of how these reforms affected firm productivity in the Indian context. In particular, I extend Krishna and Mitra's (1998) attempt to rigorously estimate the effects of trade liberalization on firm performance in Indian manufacturing for the 1986-1993 period and the recent study by Sivadasan (2006), which measures the productivity impacts of various barriers to entry in the Indian manufacturing sector. While Krishna and Mitra (1998) and Sivadasan (2006) capture the effect of liberalization through a post-reform dummy (Sivadasan uses the interaction between post-reform dummy and a dummy of whether the industry received a large decrease in output tariffs), I use firm-level panel data, employing intertemporal and across-industry variation in trade protection to identify the effect of trade policies. In addition, I study not only the effect of output tariffs on productivity, but also the impact of tariffs on intermediate inputs as well as effective rates of protection. By looking at how firms across different industries, and different economic environments responded to the trade liberalization shock, this study contributes to the debate on the need for complementary domestic policies for the productivity effects of trade liberalization.

\subsection{Productivity Measure}

To begin the analysis, I construct measures of firm-level total factor productivity (TFP) following the methodology of Levinsohn and Petrin (2003). Building on Olley and Pakes (1996), ${ }^{5}$ Levinsohn and Petrin (2003) resolve the fundamental problem of estimating production functions arising from the fact that a firm's choice of inputs is likely to be correlated with any unobserved firm-specific productivity shocks. Levinsohn and Petrin (2003) use a firm's raw material inputs as a proxy for the unobservable productivity shocks to correct for the simultaneity in the firm's

\footnotetext{
${ }^{5}$ Olley and Pakes (1996) develop a methodology in which an investment proxy controls for correlation between input levels and unobserved productivity shocks, allowing for the consistent estimation of the firm's production function. However, this methodology can only be applied to plants reporting non-zero investment, usually leading to a sizable truncation of the available data. The Levinsohn and Petrin (2003) method avoids this problem by assuming intermediate inputs are strictly monotonic in productivity. As intermediate input demand is typically much less lumpy than investment, the strict monotonicity assumption is more likely to hold.
} 
production function. ${ }^{6}$ The inclusion in the estimation equation of a proxy that controls for the part of the error correlated with inputs ensures that the variation in inputs related to the productivity term will be eliminated. Assuming a Cobb-Douglas production function, the equation estimated for company $i$ in industry $j$ at time $t$ in the first step can be written as follows:

$$
y_{i t}^{j}=\alpha+\beta_{l} l_{i t}^{j}+\beta_{p} p_{i t}^{j}+\beta_{m} m_{i t}^{j}+\beta_{k} k_{i t}^{j}+\omega_{i t}^{j}+\epsilon_{i t}^{j}
$$

where $y$ denotes output, $l$ denotes labor, $p$ denotes power and electricity expenditures, $m$ denotes raw material expenditures, and $k$ denotes capital used; all variables are expressed in natural logarithm. The simultaneity problem arises from the $\omega_{i t}^{j}$ term, a firm-specific, time varying productivity shock that cannot be observed by the econometrician but which is correlated with the firm's choice of variable inputs, $p, m$, and $l$. Levinsohn and Petrin (2003) show that if the demand function for intermediate inputs is monotonic in the firm's productivity for all relevant levels of capital, i.e. $m_{i t}^{j}=m_{t}^{j}\left(\omega_{i t}^{j}, k_{i t}^{j}\right)$ then raw materials can serve as a valid proxy. Inverting the raw materials demand function gives an expression for productivity as a function of capital and raw materials $\omega_{i t}^{j}=\omega_{t}^{j}\left(m_{i t}^{j}, k_{i t}^{j}\right)$. This expression can be substituted in equation (1) and the coefficients on the variable inputs: $l$ and $p$ can be estimated using semiparametric techniques. In a second stage, the coefficients on $k$ and $m$ are recovered using GMM techniques with the identifying assumption that productivity follows a Markov process and capital adjusts to productivity with a lag. ${ }^{7}$

Using a process described in detail in Levinsohn and Petrin (2003), I derive consistent estimates of the parameters of the production functions for each industry $j .^{8}$ Due to the small number of companies in some of the 4-digit level industries, the production function parameters were estimated at the 2-digit National Industrial Classification codes. I allow for the input demand function as well as the production function to differ across two periods: before 1996

\footnotetext{
${ }^{6}$ If productivity is assumed time-invariant, the simultaneity problem may be solved by including firm fixedeffects (Harrison, 1994 and Balakrishnan et al., 2000). However, this strategy may not be appropriate when interested in changes in firm-level productivity. Under certain conditions and if appropriate instruments are available, the Arellano-Bond estimator could also overcome the simlutaneity problem. However, the data requirements could not be met with the current data source.

${ }^{7}$ For a detailed description of the production function estimation methodology, see Levinsohn and Petrin (2003).

${ }^{8}$ See Appendix for details on variables and deflators.
} 
(a period of very high economic growth) and after 1996 (a relative slowdown). In this way, I partially address the concern that the changing economic environment may have affected the relative input and output prices, which are not included in the raw materials demand estimation. Using the input coefficients obtained with the Levinsohn and Petrin methodology, I obtain estimates of a firm's Hicks-neutral TFP by subtracting firm $i$ 's predicted output from its actual output at time $t$. In order to make the estimated TFP comparable across industries, I create a productivity index ${ }^{9}$ following the standard methodology in the literature (Aw, Chen, and Roberts, 2001).

Since data on physical quantities of output, capital and intermediate inputs are not available, the productivity estimation follows the literature by proxying these variables with deflated sales revenue, capital spending and input expenditures. Ideally one would use firm-specifc price deflators to arrive at the deflated sales, capital spending etc. Unfortunately, as is the case in most firm-level datasets, such information is not available. In addition, the only deflators to my knowledge available for India (and used in this paper), are not specific to a particular geographic location; they are only specific to the industry. Thus, the productivity measure captures both technical efficiency as well as price-cost markups (Katayama et al. 2006), and the estimated coefficients on trade protection may reflect the response of price-cost mark-ups, rather than actual productivity to changes in output and import tariffs. However, as long as price-cost markups are correlated with true efficiency (as models such as Bernard et al. (2003) would predict), then the revenue-based TFP measure captures technical efficiency. ${ }^{10}$

\footnotetext{
${ }^{9}$ The productivity index is calculated as the logarithmic deviation of a firm from a reference firm's productivity in the particular industry in a base year. In other words, we subtract the productivity of a firm with the mean $\log$ output and mean log input level in 1989/90 from the estimated firm-level TFP.

${ }^{10}$ In Section 4.1.4, I check the sensitivity of the results to a range of alternative definitions of productivity, such as labor productivity or a direct measure of technical efficiency. The results are robust across the different proxies for true efficiency. This finding is in line with a recent study by Van Biesebroeck (2006) that suggests that an array of methodologies for estimating productivity yield very similar rankings of productivity, even though the estimated input elasticities vary widely.
} 


\subsection{Empirical Strategy}

The empirical strategy employed in this paper exploits the specific timing as well as the differential degree of liberalization across industries to identify the effect of trade policy on firm-level productivity. Although I build on the methodology of Pavcnik (2002), Fernandes (2007) and Amiti and Konings (2005), compared to these studies, I benefit from both a rather clean natural experiment of trade liberalization coming from external factors and the availability of data before and after trade reforms. In this context, the baseline specification takes the following form:

$$
p r_{i t}^{j}=\alpha+\beta \cdot \operatorname{Trade}_{t-1}^{j}+X \cdot \gamma+Y_{t}+I^{j}+v_{i t}^{j}
$$

where $p r_{i t}^{j}$ is the productivity index of company $i$ in industry $j$ at time $t$; $\operatorname{Trade}_{t-1}^{j}$ is a measure of lagged trade protection at the 4-digit National Industrial Classification (NIC) level; and $X$ is a set of company characteristics, including age, age squared, ownership categories (private stand alone, private group, government-owned, and foreign firms), and size categories (large, if average sales over the entire period are in the top 1 percent of the distribution; medium, if sales are greater than the median, excluding the top 1 percentile; and small if average sales over the period are less than the median). $Y_{t}$ is a set of year dummies and $I^{j}$ are industry fixed effects. The inclusion of industry fixed effects absorbs unobserved heterogeneity in the determinants of productivity that are industry-specific, while the year dummies control for macroeconomic shocks common to all firms. I am interested in the magnitude and sign of the coefficient on lagged trade protection, $\beta$, which captures the percentage change in firm-level productivity associated with industry level differences in trade protection.

Not controlling for lagged productivity in equation (2) however is inconsistent with the assumption that TFP follows a Markov process in the estimation of the production function. Fernandes (2007) addresses the problem of serial correlation by controlling for lagged productivity, potentially introducing some bias from the inclusion of both fixed effects and lagged dependent variable. I build on her methodology by estimating equation (2) using the Arellano and Bond (1991) GMM technique for dynamic panels with lagged dependent variable.

Most previous studies have focused on the nominal tariffs faced by an industry as a measure of trade protection. Using nominal tariffs is attractive as tariffs are both well measured and 
comparable across time. However, at a time when the structure of output tariffs across industries undergoes such a drastic change (see Figure 1, Panel E and F), the disciplining effect of lowering output tariffs may be undermined by lower tariffs on intermediate inputs (Amiti and Konings, 2005, Corden, 1971). Thus, in addition to using nominal tariffs, I also construct effective rates of protection (ERP) as defined by Corden (1966), which capture the net effect of lowering tariffs on output and intermediate inputs:

$$
\operatorname{erp}_{t}^{j}=\frac{\text { OutputTariff } f_{t}^{j}-\sum_{s} \alpha_{s}^{j} \cdot \operatorname{InputTariff} f_{s t}^{j}}{\left(1-\sum_{s} \alpha_{s}^{j}\right)}
$$

In the above formula $\alpha_{s}^{j}$ is the share of input $s$ in the value of output $j$.

Finally, I attempt to disentangle the productivity impacts caused by lower output tariffs from those caused by lower tariffs on intermediate inputs. As Amiti and Konings (2005) point out, the direct effect of cheaper inputs may be to decrease firms' incentives to improve technical efficiency. However, lower input tariffs increase the access to foreign intermediates, capital goods and technology, creating opportunities for learning and productivity improvements. Following Schor (2004) and Amiti and Konings (2005), I construct an industry j's input tariff as: ${ }^{11}$

$$
\text { InputTariff } f_{t}^{j}=\sum_{s} a_{s}^{j} \cdot \operatorname{InputTariff} f_{s t}^{j}
$$

Table A1 provides the evolution of the different measures of trade protection over time.

\subsection{Data Description}

A firm-level dataset is compiled from the Prowess database, which contains information primarily from the income statements and balance sheets of publicly listed companies. ${ }^{12}$ The companies in the database together comprise more than 70 percent of the economic activity in the organized industrial sector of India. The size of the dataset, which covers the period 1989-2001, varies by year (Table A2). As this is not a census of all manufacturing firms in India and firms are

\footnotetext{
${ }^{11}$ Note that the definition of input tariffs differs slightly from the one used by Schor (2004) and Amiti and Konings (2005) who define input tariffs as InputTarif $f_{t}^{j}=\sum_{s} \theta_{s}^{j} \cdot$ InputTarif $f_{s t}^{j}$ where $\theta_{s}^{j}$ is the share of input $s$ in the total inputs' cost of output $j$. The results presented in this paper are robust to their definition though, as expected, the magnitude of the coefficient on input tariff is substantially larger.

${ }^{12}$ The Prowess database comprises firm-level data collected by the Centre for Monitoring the Indian Economy (CMIE), a private company in India.
} 
under no legal obligation to report balance sheet and other details to the data collecting agency, information for some firms for some years is missing. Even though firms that exit and reenter the database are excluded, the exit from the database may not necessarily indicate that the firm has exited the industry. Thus, I use an unbalanced panel of companies for estimation purposes. I verify the robustness of the results by conducting the analysis using only the subset of companies whose information is available for all years. The dataset contains information on about 4,100 individual manufacturing companies. Firms are categorized by industry according to the 4digit 1998 NIC code, and span the industrial composition of the Indian economy. There are 116 industries represented in the sample. The largest sectors, measured by the number of companies, are chemicals and basic metals, and manufactures of food products, beverages, and textiles. For the estimation of the production function and TFP, all relevant variables were deflated using all-India wholesale industry-specific deflators published by the Ministry of Industry. Table A3 provides some summary statistics on the dataset.

The data on firm economic activity are complemented with measures of trade protection. I construct a database of annual tariff data for 1987-2001 at the six digit level of the Indian Trade Classification Harmonized System (HS) Code based on various publications of the Ministry of Finance. I then match about 5,000 product lines to the 116 NIC codes, using the concordance by Debroy and Santhanam (1993), to calculate average industry-level tariffs. I combine these industry-level output tariffs with the Input Output Transaction Table from 1993-1994 and calculate industry input tariffs and effective rates of protection. I define input tariff of an industry as the weighted average of the tariffs of its inputs, where the weights are the value shares. I calculate effective rates of protection as defined by Corden (1966), which take into account the effects of tariffs on inputs as well as on outputs.

As trade liberalization was concurrent with other reforms that could potentially generate productivity gains, I compile industry-specific time-varying measures of delicensing and openness to foreign direct investment. The source for these series are various publications of the Handbook of Industrial statistics.

Previous studies have also used volume measures, such as import penetration, in order to capture the importance of actual exposure to foreign competition. However, import volumes are endogenously determined; while increased competition is expected to cause firms to become 
more productive, the Ricardian model of trade predicts that certain goods may be imported precisely because domestic productivity in that industry is low (Fernandes, 2007). Thus, the preferred measures of trade policy are lagged nominal tariffs, effective rates of protection and input tariffs.

\subsection{Endogeneity of Trade Policy}

Before proceeding with estimating equation (2), I address the concern of the possible endogeneity of trade policy, which could potentially invalidate the empirical strategy. Specifically, the timing of trade reform might have reflected Indian authorities' perception of domestic industries as mature enough to face foreign competition. The cross-sectional variation in changes of protection might be related to economic and political factors. The relatively less efficient industries might have enjoyed higher degree of protection; the political strength of labor as well as business is also often cited as a determinant of trade protection. If authorities did not liberalize as intensively the least productive industries, one might observe small decline in tariffs associated with small increases in productivity and erroneously conclude that trade liberalization boosted productivity.

While several studies of India's reform argue that the external crisis of 1991 came as a surprise and opened the way for market-oriented reforms (Hasan et al., 2003, Goyal, 1996, Varshney, 1999) ${ }^{13}$ the significant variation in the tariff changes across industries could confound inference. More precisely, it is important to understand whether the changes in tariffs reflected authorities' perceptions of industry's ability to compete internationally, or the lobbying power of the industry. Ideally, this question could be answered with a "true" and objective account of the reform process. Lacking that, I instead look within the data for possible confounding relationships.

First, I investigate to what extent tariffs moved together. An analysis of the tariff changes of the 5,000 items in the dataset for 1992-96, the Eighth Plan, and for 1997-2001, the Ninth Plan, reveals that movements in tariffs were strikingly uniform until 1997 (Figure 3). During

\footnotetext{
${ }^{13}$ This view is confirmed in a recent interview with Dr. Chelliah, one of the masterminds of the reforms "We didn't have the time to sit down and think exactly what kind of a development model we needed...there was no systematic attempt to see two things; one, how have the benefits of reforms distributed, and two, ultimately what kind of society we want to have, what model of development should we have?," July 5, 2004 http://in.rediff.com/money/2004/jul/05inter.htm
} 
the first 5-year plan that incorporated the economic reforms of 1991, India had to meet certain externally imposed benchmarks, and the majority of tariff changes across products exhibited similar behavior (either increased, decreased, or remained constant each year). After 1997, tariff movements were not as uniform. Policymakers may have been more selective in setting product tariffs during 1997-2001, and the problem of potential cross-sectional endogenous trade protection is more pronounced.

A second check uses data from the Annual Survey of Industries to test for "political protection." Following the literature, I test whether measures of trade protection are correlated with politically important characteristics of the industry by regressing the change in output tariffs, input tariffs and effective rates of protection between 1987 and 1997 on various industrial characteristics in 1987. ${ }^{14}$ These characteristics include employment size (a larger labor force may lead to more electoral power and more protection), output size, average wage (policy makers may protect industries where relatively low skilled/vulnerable workers are employed), concentration (measured by the average factory size, which captures the ability of producers to organize political pressure groups to lobby for more protection), share of skilled workers and the growth of industry output and employment in the 1980s. The results are presented in Table 1. Panel A shows the correlation between change in output tariffs and industrial characteristics; Panel B the correlation between change in input tariffs and industrial characteristics; and Panel $\mathrm{C}$ the correlation between change in effective rates of protection and industrial characteristics. Tariff and ERP changes are not correlated with any of the pre-reform industry characteristics. There is a statistically significant correlation only between the change in input tariffs and the average pre-reform wage.

A possible explanation for these results can be found in Gang and Pandey (1996). They conducted a careful study of the determinants of protection across manufacturing sectors across three plans, 1979-80, 1984-85 and 1991-92, showing that none of the economic and political factors are important in explaining industry tariff levels in India. ${ }^{15}$ They explain this phenomenon with the hysteresis of policy: trade policy was determined in the Second Five Year Plan and

\footnotetext{
${ }^{14}$ The results are robust to using 1988,1989 or 1990 as the "pre" year.

${ }^{15}$ In other developing countries, protection tends to be highest for unskilled, labor-intensive sectors. See Goldberg and Pavcnik (2005), Hanson and Harrison (1999), Currie and Harrison (1997) for evidence from Colombia, Mexico and Morocco respectively.
} 
never changed, even as the circumstances and natures of the industries evolved.

The evidence presented here suggests that the differential tariff changes across industries between 1991 and 1997 were as exogenous to the state of the industries as a researcher might hope for in a real-world setting.

Finally, I investigate whether policy makers adjusted tariffs in response to industry's productivity levels. If this were the case, one should expect current productivity levels to predict future measures of trade protection. Therefore, I calculate the average industry-level productivity as the average firm-level TFP, weighted by companies' sales. I then regress industry-level output tariffs, input tariffs and ERP in period $t+1$ on industry-level productivity in period t, controlling for industry and year fixed effects and weighting each industry by the number of companies in the industry for the particular year. The results are presented in Table 2. The correlation between future trade protection and current productivity is indistinguishable from zero for the 1989-96 period for all three measures used in the study. The 1997-2001 period, however, is different. The coefficient on current productivity is negative and significant at the 1 percent level, suggesting that trade policy may have been adjusted to reflect industries' relative performance. ${ }^{16}$

This test implies that to correctly identify the effect of trade policies on productivity, one should restrict attention to the period immediately before and after the major trade reforms (1989-96). While there is no evidence that variation in tariffs may have been used to selectively protect the less productive industries during this period, I nevertheless follow Fernandes (2007) and estimate the effect of lagged rather than contemporaneous tariffs. ${ }^{17}$ Including industry fixed effects also absorbs time-invariant political economy factors underlying trade protection across industries.

\footnotetext{
${ }^{16}$ In an alternative specification presented in Appendix Table 4, I also condition on the current tariff, thus de-facto performing a Granger causality test for panel data. Conditional on current tariffs, current productivity adds no information to explanation of movements of future tariffs in the 1989-1996 period. However, in 1997-2001, there is a strong statistically significant relationship between current productivity and future tariffs.

${ }^{17}$ Lagged tariffs are also more appropriate when productivity adjustments do not occur instantaneously.
} 


\section{Results}

\subsection{Average Impact of Trade Policy and Robustness}

\subsubsection{Average Impact of Output Tariffs}

The results from estimating equation (2) for the period 1989-96 with output tariffs as a measure of protection are presented in Table 3 (Panel A). The regression in column (2) includes industry fixed effects at the 4 digit level. Column (3) includes firm-level fixed effects, and in column (4) I repeat the analysis on the balanced panel of companies. In column (5) I control for lagged productivity as Fernandes (2007) to address the problem of serial correlation in equation (2). However, including the lagged dependent variable in a fixed effects model renders the estimates inconsistent, thus column (6) and (7) contain the results from the Arellano and Bond (1991) GMM technique for dynamic panels with lagged dependent variables with one and two lags respectively. The related specification tests are also presented. Finally in column (8), I present estimates from the 'direct approach' of estimating the productivity impacts of trade reforms suggested by Fernandes (2007) in which the measures of trade policy are included in the production function itself. ${ }^{18}$ In all specifications in columns (1)-(5), the standard errors are corrected for heteroskedasticity and adjusted for clustering at the firm level to account for possible serial correlation of the error term. The standard errors in column (8) are bootstrapped using the block-boostrapping method described in Efron and Tibshirani (1994), which takes into

\footnotetext{
${ }^{18}$ This approach corrects for the inconsistency introduced by the assumption that current productivity depends on lagged trade protection, which is known to the firm, while the Markov process of productivity assumes that the current productivity realization is a surprise conditional on lagged productivity. Thus, Fernandes (2007) modifies the Levinsohn and Petrin (2003) estimator by including lagged trade policy directly in the production function equation, and assuming that firm's productivity is monotonically increasing in firm's raw materials, for all relevant levels of capital and trade policy. The data for all firms across all industries and years are pooled, the production function is augmented with industry and year fixed effects, and a vector of firm characteristics (namely age and age squared). Using a process similar to Levinsohn and Petrin (2003), the coefficients on the variable inputs are estimated using semiparametric techniques, while the coefficient on capital, trade policy and raw materials are recovered using non-linear least squares. Fernandes (2007)'s correction of the inconsistency in the two-step approach comes at the expense of estimating one production function for all industries and not being able to control for firm fixed effects. Thus, I use the direct approach mostly as a robustness check. For a detailed description of the 'direct approach,' see Fernandes (2007).
} 
account the serial correlation in the data by keeping all observations that belong to the same firm together.

The estimates of $\beta$ are robust across a wide variety of specifications. The coefficient of interest, the impact of lagged tariffs, is -.053 in the base specification with firm fixed effects presented in column (3). Decreasing trade protection in the form of lower output tariffs raises productivity at the firm level. Since productivity is measured in log terms, this implies that a 10 percent reduction in tariffs (at the 4 digit industry level) leads to a .53 percent increase in TFP. The results are highly statistically significant, and similar in magnitude to the estimates of Fernandes (2007), Schor (2004) and Amiti and Konings (2005).

If the high level of protection before trade reforms allowed companies with different levels of productivity to coexist, the higher average productivity associated with tariff reductions could be due to the exit of the least efficient producers without any change in the productivity of the surviving plants, as shown by Melitz (2003). Although the Prowess database, which covers only publicly listed companies, does not allow the rigorous study of entry and exit behavior of firms, column (4) presents some suggestive evidence on whether the productivity gains arise through that channel. I estimate equation (2) only for the set of companies in operation throughout the entire period. The positive impact of tariff reductions on productivity levels is virtually unchanged. While the exit of less efficient companies might contribute to productivity improvements, it does not drive the results within this sample. The data shortcomings notwithstanding, I also perform the exercise of allocating the productivity gains that stem from reshuffling of resources from the less to more efficient firms vs. increases in the average productivity within a firm using the methodology in Olley and Pakes (1996) and Pavcnik (2002). ${ }^{19}$ Within this sample, aggregate productivity increased by about 10 percent between 1989-1996, with almost all the aggregate productivity gains driven by substantial growth in average firm productivity, rather than reallocation of market share towards more productive firms. As pointed above, this could be due to the fact that instead of using a census of all manufacturing firms, I study the effects of trade reforms in a selected sample of larger and possibly more established companies

\footnotetext{
${ }^{19}$ This methodology decomposes weighted aggregate productivity at the industry level into two parts: the unweighted aggregate productivity measure and the total covariance between a firm's share of the industry output and its productivity. An increase in the covariance suggests that more productive firms are increasingly producing larger shares of output. Results are available from the author upon request.
} 
with easier access to credit. Alternatively, this finding may point to substantial barriers to exit in the Indian economy, as argued in Topalova (2005). Thus, the productivity gains associated with trade liberalization seem to stem mostly from productivity improvements within the firm, at least in the sample of publicly listed companies.

Controlling for lagged productivity or using the Arellano Bond estimator (columns 5-7) yield similar in magnitude and statistically significant estimates. Finally, the impact of trade policy on productivity when estimated using the direct approach is substantially larger in magnitude (as in Fernandes, 2007). Note however, that the estimates in the direct and indirect approach are not really comparable as the direct approach assumes the same production function across all industries and does not control for company fixed effects.

\subsubsection{Average Impact of Effective Rates of Protection}

Focusing on nominal output tariffs may give a misleading picture of the impact of the comprehensive trade liberalization in India, if the competitive pressure on the output side was undermined by the availability of cheaper inputs. To capture the net competition effect of trade reform, Panel B in Table 3 presents the results from estimating equation (2) using effective rates of protection as a measure of trade liberalization. ${ }^{20}$ Lower effective rates of protection increase firm productivity: a 10 percent reduction in ERP leads to 0.25 percent increase in TFP. The estimated effects are similar in magnitude and robust across all specifications. The estimations using this alternative measure of trade protection also suggest that the productivity effect comes from changes within the firm.

\subsubsection{Average Impact of Input Tariffs}

While the effective rates of protection reveal the net competition effect of trade liberalization, it is interesting to separate the impact of lowering output tariffs versus lowering tariffs of intermediate inputs. I reestimate equation (2) including both output as well as industry input tariffs. The results are presented in Table 4, which mirrors the specifications in Table 3. The inclusion of the

\footnotetext{
${ }^{20}$ Note that unlike output tariffs, ERP suffer from potentially important measurement error as they were calculated using the input-output matrix from 1993. Thus, I am abstracting from the variation in ERP due to changes in an industry input mix.
} 
input tariff slightly reduces the estimated impact of output tariffs, though the differences are not statistically significant. Both reduction in output and reduction in input tariffs lead to higher productivity levels. The magnitude of the coefficient on input tariffs varies substantially across specifications, though similarly to Amiti and Konings (2005), it is larger than the coefficient on output tariffs. A 10 percent decrease in input tariffs leads to a 2.5-4.8 percent increase in productivity, while the same decrease in output tariffs increases productivity by $0.32-0.59$ percent. $^{21}$

The results suggest that an important way through which trade reforms induce productivity growth is through the intermediate inputs channel: the potentially wider choice of varieties of possibly higher quality and exposure to new technologies through imported inputs. This finding is in line with Hasan (2002)'s study of the impact of imported technologies on productivity in India. Using a panel of firms from 1975 to1985, Hasan (2002) finds that imports of disembodied technology have a significant positive effect on firm's productivity. Within the Prowess sample, spending on foreign raw materials and capital goods is positively correlated with firm productivity (conditional on firm and year fixed effects). In developing countries, the productivity enhancing impact of imported intermediates has been also established by Kasahara and Rodrigue (2004) in the context of Chile and Muendler (2004) in Brazil.

\subsubsection{Alternative productivity measures}

Table 5 investigates whether the findings are sensitive to the measure of productivity. In Panel A, the effect of nominal tariffs is presented. Panel B shows the impact of effective rates of protection while Panel $\mathrm{C}$ disentangles the different impacts of output and input tariffs. I focus on four of the specifications presented in Tables 3 and 4: columns (1), (5), (9) and (13) include industry fixed effects, columns (2), (6), (10) and (14) include firm fixed effects, columns (3), (7), (11) and (15) present the Arellano Bond estimator with one lag, while columns (4), (8), (12) and (16) present the Arellano Bond estimator with two lags. In columns (1)-(4), the measure of firm productivity is TFP estimated using OLS; in columns (5)-(8) TFP is derived using input

\footnotetext{
${ }^{21}$ Note that the variation in input tariffs is substantially smaller; the standard deviation in input tariffs is 0.09 vs 0.28 in the output tariffs. A log-log specification suggests that elasticity of productivity with respect to input tariffs is about three times larger than with respect to output tariffs.
} 
cost shares as proxy of input coefficients; columns (9)-(12) use the log of labor productivity, which is defined as gross value added divided by labor expenditure (the number of employees is not reported in the Prowess data). Finally, in columns (13)-(16) I estimate the impact of trade liberalization on the log of the average days of finished goods stock, a proxy for technical efficiency that does not suffer from measurement issues from potentially using incorrect deflators, misspecifying the production function etc.

Across all measures of productivity and in almost all specifications, reductions in output tariffs and effective rates of protection lead to higher productivity levels. Lowering input tariffs is also associated with productivity gains. Across all measures, the estimated impact of input tariffs is substantially larger in magnitude than the competitive effect captured by output tariffs and effective rates of protection.

\subsection{Average Impact of Trade Policy and Industrial Characteristics}

Trade liberalization allows us to examine whether the regulatory environment in which different industries operated shaped how firms in these industries responded to trade liberalization. First, I study whether the presence of non-tariff barriers (NTB) to trade reduced the competitive effect of output tariff reductions. I classify the 4-digit industrial codes based on the output of the industry as Basic, Intermediate, Capital Goods, Consumer Durables and Consumer NonDurables (Nouroz, 2001). While the reduction in output tariffs across the different industries was roughly similar in the 1989-1996 period (Figure 1, Panel C), Figure 1, Panel D reveals that nontariff barriers (as measured by the share of product lines that require any license to be imported) were eased at a slower pace. Only 34 percent of product lines could be imported without any license by 1996 among the set of Consumer Non-Durables industries, as compared to 93 percent for the set of Basic industries. As data on non-tariff barriers are not available at a disaggregated level, especially for the pre-reform period, to implicitly account for the potential impact of NTBs, I reestimate equation (2) for two groups of industries: Basic, Intermediate and Capital goods, the group that experienced substantial reduction in NTBs, and Consumer Non-Durables and Consumer Durables, which remained relatively protected from foreign competition. If NTBs were an important part of trade protection in India, one would expect the roughly similar tariff reductions across the broad industry groups to have a differential impact on productivity. Table 
6 confirms that this is indeed the case. Table 6 presents the results from estimating equation (2) for the two sets of industries separately, with firm fixed effects in columns (1) and (3) and the Arellano Bond estimator in columns (2) and (4). ${ }^{22}$ Panel A presents the result with output tariff as a measure of trade protection, Panel B uses effective rates of protection, while in Panel $\mathrm{C}$, both output and input tariffs are included. The impact of the reduction in output tariffs and effective rates of protection were much larger for Basic, Intermediate and Capital goods industries. There is no evidence that these tariff reductions resulted in substantial increases in productivity in the Consumer Goods category. The impact of input tariffs is not precisely estimated for the Basic, Intermediate and Capital goods industries.

Domestic industrial policy may have also affected the way firms responded to foreign competition. In particular, I examine whether the productivity impact of trade reforms was related to the extent to which an industry was subject to licensing at the onset of the trade liberalization reforms. ${ }^{23}$ Following Aghion et al. (2005) and using various publications of the Handbook of Industrial Statistics, I construct an industry level 'license' variable, which denotes the share of products within a 4-digit industry that are subject to licensing. Using the industry-level manufacturing census for 1980-1997, Aghion et al. (2005) find that delicensing was associated with significant entry into an industry. I define highly regulated industries as of 1989 as those for which $100 \%$ of products are subject to licensing and split the sample according to this criteria. Not surprisingly, the competitive pressure of trade reforms did not spur productivity gains in firms in the most regulated industries, as they were unable to change their production technology, input mix or manufacturing scale. The results are presented in columns (5)-(8) of Table 6. While these findings do not warrant a causal interpretation as the regulation status of an industry in 1989 was potentially correlated with other factors that might have affected firms' response to tariff reductions, it is in line with the cross-country evidence presented by Bolaky and Freund (2004) that the growth effect of trade depends on the business regulation in a country.

\footnotetext{
${ }^{22}$ For the sake of brevity I present the results from the Arellano Bond estimator with two lags from now on, as the related specification test is rejected for some subsamples when using only one lag.

${ }^{23}$ The licensing of industries, outlined in the Industries (Development and Regulation) Act of 1951, was one of the most important tools of the Indian government to control private enterprize in India. According to the Act, a license was required in order to establish a new factory, expand capacity by more than $25 \%$ of existing levels or manufacture a new product (Aghion et al. 2005).
} 
One might also expect the impact of reductions in trade protection to be larger for industries that actually compete with foreign imports. In columns (9)-(12) of Table 6 , I reestimate equation (2) for export-oriented and non-export oriented industries (which include import-competing and non-traded industries). ${ }^{24}$ As expected, the disciplining effect of trade liberalization is much larger for the non-export-oriented industries.

\subsection{Average Impact of Trade Policy and Company Characteristics}

So far, I have established that there is some evidence to suggest that certain industrial characteristics such as regulatory burden, exposure to NTBs and exporting status matter for the transmission of the trade liberalization shock. Might also company characteristics such as firm size or ownership affect the way firms respond to lower trade protection? I investigate whether the effect of lower protection on productivity is different for foreign companies. Although firm size is arguably endogenous (as a firm's size in the years before the reform may be directly related to firm's productivity), I examine whether size is correlated with firm's ability to adapt to a new environment. The results are presented in Table 7. Panel A presents the result with output tariff as a measure of trade protection, Panel B uses effective rates of protection, while in Panel C, both output and input tariffs are included. For each subgroup of firms, I estimate equation (2), allowing for firm and year fixed effects in columns (1), (3), (5), (7) and (9), and using the Arellano Bond estimator in columns (2), (4), (6), (8) and (10).

Columns (1)-(4) of Table 7 provide some suggestive evidence that while the competitive pressure from trade liberalization raises productivity in domestically owned companies, the same increase in efficiency may not be experienced by foreign companies. Although the coefficients on lagged tariffs, effective rates of protection and input tariffs are imprecisely estimated, the point estimates in the sample of foreign enterprises are somewhat smaller in magnitude than those for domestic firms and statistically insignificant. This finding is not surprising given that foreign firms were already exposed to foreign competition and learning opportunities from superior intermediate inputs.

The results also suggest that the disciplining effect of foreign competition was roughly similar across companies of different size and there is no difference in how companies of different sizes

\footnotetext{
${ }^{24}$ For the classification of industries I rely on Nouroz (2001).
} 
reacted to lower input tariffs.

\subsection{Average Impact of Trade Policy and Environment Characteristics}

I finally investigate whether certain external features of the environment in which firms operate, such as institutions, geography, and level of development affect the way firms respond to lower trade protection? ${ }^{25}$ I test for these differences in Table 8, presenting results using output tariffs, effective rates of protection and output and input tariffs respectively. The specifications presented mirror those in Tables 6 and 7 .

First, I look at whether firms that are located in coastal states were more affected by the reform. ${ }^{26}$ In a country where product markets might not be fully integrated across regions due to the sheer size of the country as well as poor infrastructure, firms in the heart of the country or in less accessible regions might not experience the threat of increased foreign competition or access imported intermediate inputs as much as firms in regions in more immediate contact with internationally traded goods. However, columns (1)-(4) of Table 8 do not confirm this hypothesis. If anything, the point estimates of the effect of output tariffs and effective rates of protection are slightly larger in magnitudes for the set of firms operating in non-coastal states.

I examine the role of institutions, focusing on state labor laws. Using Besley and Burgess (2003) classification of states' labor laws as pro-worker, neutral, or pro-employer labor laws, one can see in columns (5)-(8) that there is little difference in the estimated impact of reduction in trade protection, and if anything, the firms in states with neutral and pro-worker labor laws seem to benefit more from the trade reforms.

The level of financial development of the state (measured as credit per capita in 1992, with states above the median classified as having "high financial development") also makes no difference (columns (9)-(12)). This finding is unexpected since a major concern regarding trade liberalization has been the ability of domestic firms to access sufficient credit to invest in more efficient technologies and survive in the face of foreign competition.

\footnotetext{
${ }^{25}$ See Table A5 for the classification of states by various categories.

${ }^{26}$ Since the Prowess data are at the company rather than plant level, a particular company may report data from business activity in more than one state. I assign companies to different states based on the location of the company's registered office. The registered office is the address each firm of more than 20 persons in India must submit to the Registrar of Companies as dictated by the Companies Act, 1956.
} 


\subsection{Trade Liberalization vs Other Reforms}

The 1991 trade liberalization was part of a package of reforms, which included further delicensing and relaxation of foreign direct investment rules. Both of these reforms aimed at increasing domestic competition, thus potentially enhancing productivity. If reduction in output tariffs across industries and over time is correlated with the process of delicensing and opening to FDI, then the empirical strategy could erroneously attribute the impact of these other reforms to trade liberalization. To control for the concurrent reforms, I compile an industry level data set on industry-specific time-varying measures of licensing and openness to foreign direct investment for 1989-1996 from various publications of the Handbook of Industrial Statistics. In Table 9, I present the results from estimating equation (2) but controlling for lagged openness to FDI (columns (1), (2)), controlling for lagged licensing (column (3), (4)), and controlling for both lagged openness to FDI and lagged licensing. Results from a specification with firm fixed effects and the Arellano Bond estimator are presented. The effect of trade liberalization on productivity (measured either as TFP (Panel A) or labor productivity (Panel B)) is completely insensitive to the additional controls. In some specifications, more intensive delicensing is associated with significantly higher TFP and in all specifications with significantly higher labor productivity. The correlation with openness to FDI is most often indistinguishable from zero. So while there is some evidence that the introduction of domestic competition was associated with enhanced firm productivity, trade liberalization boosted productivity in and of itself.

It is also interesting to examine whether there is complementarity between different industrial policies, that encourage competition either through entry of domestic firms or imports of final products. In column (7) and (8) of Table 9, I interact trade policy with openness to FDI and industrial regulation through licenses. Again, while one should refrain from causal interpretation, the evidence suggests that there may be strong complementarity between different industrial policies. The impact of trade reforms appears to be magnified as foreign direct investment was allowed or restrictive licensing requirements were removed, a finding that is robust across all specifications and measures of productivity. The increase in productivity from of a 10 percent reduction in tariffs in a firm, operating in an industry that saw no change in FDI rules, was 0.63 percent. The same reduction in tariffs was associated with a 2.3 percent increase in productivity for firm, for which FDI was fully liberalized during this time period (i.e. FDI went from 0 to 
1). Similarly, the increase in productivity from of a 10 percent reduction in tariffs in a firm, operating in an industry that saw no change in its licensing rules, was 0.63 percent. The same reduction in tariffs was associated with a 1.6 percent increase in productivity for firm, that was completely deregulated during this time period (i.e. License went from 1 to 0 ). This evidence, though suggestive, points to the need for complementary domestic policies that can help firms' adjustment to globalization as argued in Hoekman and Javorcik (2004).

\section{Conclusion}

How trade liberalization affects the productivity of domestic firms is a question of vital importance for both trade theory and economic policy. Yet, answering this question requires overcoming a severe identification problem: since trade policy is determined by governments that have and respond to specific interests, changes in trade protection are likely to be correlated with other important factors, which likely affect firm productivity.

In this paper, I use a unique episode from the early 1990s, when India implemented substantial trade reforms in response to external pressure. The use of inter-temporal and inter-industry variation from over 5,000 tariff line items, over an eight year time period, allows for a flexible analysis with substantial power: year fixed effects ensure the effect of liberalization is not confounded with other macroeconomic factors, while industry fixed-effects absorb time-invariant political economy factors underlying trade protectionism across industries. The evidence yields several important lessons.

First, I demonstrate that the identification is more than a theoretical concern: as indicated in Section 3.4, when the Indian government had discretion over its liberalization policy, tariff reductions were highly correlated with current levels of productivity. Thus, empirical studies measuring the effect of liberalization without paying careful attention to the source of variation may yield inaccurate results. In contrast, several tests suggest that the changes in tariffs exploited in this paper, in the early 1990s, were not correlated with standard confounding factors.

Second, trade liberalization causes productivity increases. This gain accrues both from increased competition, but also from firms' access to a larger choice of intermediate inputs. During the 1990s, average output tariffs declined by 63, and average input tariffs declined 
by 23 percentage points, thus contributing respectively $2-4$ and $6-9$ percent increase in total factor productivity. Disaggregate trade and domestic price data point to the source of these productivity gains. Product-level data on imports and tariffs reveal that trade liberalization was associated with a significant increase not only in the volume of imports, but also in the varieties of goods imported. Firms benefited from the access to more and cheaper inputs, and the superior technology embodied in these. On the other hand, the greater competition from foreign producers put a downward pressure on domestic prices, thus forcing firms to raise their technical efficiency. While the available data does not allow disentangling the exact mechanisms underlying the efficiency gains, there is evidence that the higher competitive pressure led to more intense use of imported inputs, especially imported capital goods. Within the sample, the productivity gains seem to be driven by productivity increases in existing firms, rather than the exit of inefficient firms. There is no evidence that exploiting economies of scale or expanding export activity were a major factor behind the growth in productivity, though inference is limited by the nature of the data.

Third, I discover where tariff reductions did (and did not) have heterogeneous effects. First, I present evidence that non-tariff barriers may play an important role for protecting industries from foreign competition. The set of industries that remained relatively closed in terms of nontariff barriers throughout the period of study did not experience the productivity enhancing impact of the reductions in output tariffs. Second, the productivity impact of trade reforms stemming from increased competition were felt more strongly in import-competing industries. Finally, firms operating in industries that were subject to less regulation at the onset of the reforms were better able to respond to the competitive pressure and enhance efficiency.

Somewhat surprisingly, within this sample of firms, firm characteristics (other than industrial affiliation) and the environment in which firms operate (i.e., geography, institutions, financial development) do not appear to have any effect on the transmission of the trade liberalization shock. While there is some suggestive evidence that the productivity impact of the tariff reform was not experienced by foreign firms, as they were already exposed to international competition and had access to foreign suppliers of intermediate inputs, other firm characteristics, such as firm size, did not influence the way firms responded to lower levels of protection. This finding, which is contrary to the Colombian experience (Fernandes, 2007), may stem from the fact that 
publicly listed firms may already be substantially larger than the average firm in India

Finally, there seems to be substantial complementarity between industrial policies that increase foreign competition (namely tariff reductions) and industrial policies that enhance domestic competition, such as industrial delicensing and relaxation of foreign direct investment. The impact of trade reforms is magnified as foreign direct investment is allowed or restrictive licensing requirements are removed.

The finding that liberalization leads to higher firm-level productivity does not mean that liberalization unambiguously improves welfare, as productivity gains themselves may have costs (Tybout, 2001). Still, this paper provides strong evidence that liberalization leads to increases in productivity from both foreign competition and access to superior inputs, especially as restrictions to domestic competition were removed. A final lesson is that liberalization may lead to greater productivity gains when combined with deregulation and delicensing of firms.

\section{Appendix: Estimating the Production Function}

To estimate the production function, the following variables were used: the value of total output, gross fixed assets, salaries and wages, raw materials expenses, power and fuel expenses, and depreciation. The data provided in the Centre for Monitoring the Indian Economy (CMIE) database are drawn from companies' balance sheets and income statements. The values of output and power and fuel expenses were converted in real terms by industry-specific wholesale price indices. For salaries, wages and raw materials expenses, the wholesale price index was used.

I closely followed the methodology of Balakrishnan et al. (2000) to measure the capital employed by the firm in its production process. It applies the Perpetual Inventory Model, while correcting for the fact that the value of capital is recorded at historic and not replacement cost. In order to arrive at a measure of the capital stock at its replacement cost for a base year (in the case assumed to be 1997), I construct a revaluation factor assuming a constant rate of change of the price of capital and a constant rate of growth of investment throughout the 20 year assumed lifetime of capital stock. This revaluation factor converts the capital in the base year into capital at replacement cost at current prices, which is then deflated using a deflator constructed from 
the series on gross capital formation. To get the capital stock for every time period, I take the sum of investment in subsequent years. Table A4 provides some descriptive statistics of the variables used in the estimation of the production function.

\section{Bibliography}

Aghion, Philippe, Robin Burgess, Stephen Redding and Fabrizio Zilibotti. "Entry Liberalization and Inequality in Industrial Performance." Journal of the European Economic Association, 2005, 3(2-3), pp. 291-302.

Ahluwalia, Montek. "India's Economic Reforms. An Appraisal" in India in the Era of Economic Reforms eds. J. Sachs, A. Varshney, and N. Bajpai, New York: Oxford University Press, 2000.

Amiti, Mary and Jozef Konings. "Trade Liberalization, Intermediate Inputs, and Productivity: Evidence from Indonesia." IMF Working Paper WP/05/146, 2005.

Arellano, Manuel and Stephen Bond. "Some Tests of Specification for Panel Data: Monte Carlo Evidence and an Application to Employment Equations." Review of Economic Studies, 1991, 58(2), pp. 277-297.

Aw, Bee W., Xiaomin Chen, and Mark J. Roberts. "Firm-Level Evidence on Productivity Differentials and Turnover in Taiwanese Manufacturing." Journal of Development Economics, 2001, 66(1), pp. 61-86.

Balakrishnan, P., K. Pushpangadan and M.S. Babu. "Trade Liberalization and Productivity Growth in Manufacturing: Evidence from Firm-Level Panel Data." Economic and Political Weekly, 2000, October.

Bernard, Andrew, Jonathan Eaton, J. Bradford Jensen and Samuel Kortum. "Plants and Productivity in International Trade.” American Economic Review, 2003, 93(4), pp. 12681290.

Besley, Timothy and Robin Burgess. "Can Labor Regulations Hinder Economic Performance? Evidence From India." Quarterly Journal of Economics, 2004, 119(1), pp. 91-134. 
Bolaky, Bineswaree and Caroline Freund. "Trade, Regulations and Growth." unpublished manuscript, 2004.

Central Statistical Organization. Input-Output Transactions Table 1993-94. Ministry of Statistics and Programme Implementation, Government of India, 2000.

Cerra, Valerie and Sweta Saxena. "What Caused the 1991 Currency Crisis in India?" IMF $\mathrm{WP} / 00 / 157,2000$, October.

Chopra, Ajai, Charles Collyns, Richard Hemming and Karen Parker. "India: Economic Reform and Growth." IMF Occasional Paper No. 134, 1995, December.

Corden, Max W. "The Structure of a Tariff System and the Effective Protective Rate." Journal of Political Economy, 1966, 74, (June), pp. 221-237.

Corden, Max W. The Theory of Protection. Oxford University Press, 1971.

Currie, Janet and Ann Harrison. "Sharing the Costs: The Impact of Trade Reform on Capital and Labor in Morocco." Journal of Labor Economics, 1997, 15(3), Part 2, pp. 44-71.

Debroy B. and A. T. Santhanam. "Matching Trade Codes with Industrial Codes." Foreign Trade Bulletin, 1993, 24(1).

Efron, Bradley and Robert Tibshirani, An Introduction to the Bootstrap, Monograph in Applied Statistics and Probability, No. 57 (New York, NY: Chapman and Hall, 1994).

Ethier, Wilfred. "National and International Returns to Scale in the Modern Theory of International Trade." American Economic Review, 1982, 72, pp. 389-405.

Epifani, Paolo. "Trade Liberalization, Firm Performance and Labor Market Outcomes in the Developing World. What Can We Learn from Micro-Level Data?" Rivista Italiana delgi Economisti, 2003, pp. 113-144.

Fernandes, Ana. "Trade Policy, Trade Volumes and Plant-Level Productivity in Colombian Manufacturing Industries." Journal of International Economics, 2007, 71(1), pp. 52-71.

Gang, Ira and Mihir Pandey. "Trade Protection in India: Economics vs. Politics?" University of Maryland Working Paper No. 27, 1996. 
Goldar, B. "Trade Liberalization and Manufacturing Employment." Employment Paper 2002/34, International Labor Organization, 2002.

Goldberg, Pinelopi and Nina Pavcnik. "Trade, Wages, and the Political Economy of Trade Protection: Evidence from the Colombian Trade Reforms." Journal of International Economics, 2005, 66(1), pp. 75-105.

Goyal, S. K. "Political Economy of India's Economic Reforms." ISID Working Paper (New Delhi, India: Institute for Studies in Industrial Development), 1996.

Grossman, Gene and Elanahan Helpman. Innovation and Growth in the Global economy, MIT Press, 1991.

Hanson, Gordon and Ann Harrison. "Trade and wage inequality in Mexico." Industrial and Labor Relations Review, 1999, 52(2), pp. 271-288.

Harrison, Ann. "Productivity, Imperfect Competition and Trade Reform." Journal of International Economics, 1994, 36(1), pp. 53-73.

Hasan, Rana. "The Impact of Imported and Domestic Technologies on the Productivity of Firms: Panel Data Evidence from Indian Manufacturing Firms." Journal of Development Economics, 2002, 69(1), pp. 23-49.

Hasan, Rana., Devashish Mitra and K. V. Ramaswamy. "Trade Reforms, Labor Regulations and Labor-Demand Elasticities: Evidence from India." NBER Working Paper 9879, 2003.

Helpman, Elhanan and Paul R. Krugman. Market Structure and Foreign Trade. MIT Press, 1985.

Hoekman, Bernard and Beata Smarzynska Javorcik. "Policies Facilitating Firm Adjustment to Globalization." Oxford Review of Economic Policy, 2004, 20(3), pp. 457-473.

Kasahara, Hiroyuki and Joel Rodrigue. "Does the Use of Imported Intermediates Increase Productivity?" University of Western Ontario, RBC Financial Group Economic Policy Research Institute Working Papers 20057, 2004. 
Katayama, Hajime, Shihua Lu and James R. Tybout. "Firm-level Productivity Studies: Illusions and a Solution," unpublished manuscript, 2006.

Krishna, Pravin and Devashish Mitra. "Trade Liberalization, Market Discipline and Productivity Growth: New Evidence from India." Journal of Development Economics, 1998, 56(2), pp. $447-462$.

Krueger, A. Heinz Arndt Memorial Lecture, (August), 2003.

Krugman, Paul R. "Increasing Returns, Monopolistic Competition and Internation Trade." Journal of International Economics, 1979, 9, pp. 469-479.

Levinsohn, James and Amil Petrin. "Estimating Production Functions Using Inputs to Control for Unobservables." Review of Economic Studies, 2003, 70(243), pp. 317-341.

Markusen, James R. "Trade in Producer Services and in Other Specialized Intermediate Inputs." American Economic Review, 1989, 77, pp. 85-95.

Melitz, Mark J. "The Impact of Trade on Intra-Industry Reallocations and Aggregate Industry Productivity." Econometrica, 2003, 71, pp. 1695-1725.

Muendler, Marc-Andreas. "Trade, Technology, and Productivity: A Study of Brazilian Manufacturers." CESifo Working Paper No. 1148, 2004.

Nouroz, H. Protection in Indian Manufacturing: An Empirical Study, MacMillan India Ltd., Delhi, 2001.

Olley, G. Steven and Ariel Pakes. "The Dynamics of Productivity in the Telecommunications Equipment Industry." Econometrica, 1996, 64(6), pp. 1263-1297.

Pavcnik, Nina. "Trade Liberalization, Exit and Productivity Improvements: Evidence from Chilean Plans." Review of Economic Studies, 2002, 69, pp. 245-276.

Rivera-Batiz, Luis and Paul Romer. "Economic integration and endogenous growth." Quarterly Journal of Economics, 1991, 106, pp. 531-555.

Roberts, Mark and James Tybout. Industrial Evolution in Developing Countries. Oxford University Press, 1996. 
Schor, Adriana. "Heterogeneous Productivity Response to Tariff Reduction: Evidence from Brazilian Manufacturing Firms.” NBER Working Paper 10544, 2004, June.

Sivadasan, Jagadeesh. "Productivity Consequences of Product Market Liberalization: Microevidence from Indian Manufacturing Sector Reforms." October 2006.

Stiglitz, Joseph. Globalization and Its Discontents, WW Norton and Co, 2002.

Topalova, Petia. "Trade Liberalization and Firm Productivity: The Case of India." IMF Working Paper, WP/04/28, 2004.

Topalova, Petia. "Factor Immobility and Regional Impacts of Trade Liberalization: Evidence from India." MIT mimeo, 2005.

Tybout, James "Plant and Firm-Level Evidence on "New" Trade Theories." NBER Working Paper 8418, August 2001.

Tybout, James, Jamie De Melo, and Vittorio Corbo. "The Effects of Trade Reforms on Scale and Technical Efficiency: New Evidence from Chile." Journal of International Economics, 1991, 31(3), pp. 231-250.

Tybout, James and M. Daniel Westbrook. "Trade Liberalization and the Dimensions of Efficiency Change in the Mexican Manufacturing Industries." Journal of International Economics, 1995, 39(1), pp. 53-78.

Unel, Bulent. "Productivity Trends in India's Manufacturing Sectors in the Last Two Decades." IMF Working Paper, WP/03/22, 2003.

Van Biesebroeck, Johannes. "The Sensitivity of Productivity Estimates: Revisiting Three Important Debates." forthcoming Journal of Business and Economic Statistics, 2006.

Varshney, Ashutosh. "Mass Politics or Elite Politics? India's Economic Reforms in Comparative Perspective." in India in the Era of Economic Reforms, eds. J. Sachs, A. Varshney, and N. Bajpai, New York: Oxford University Press, 2000.

Young, Alwyn. "Learning by Doing and the Dynamics Effects of International Trade." Quarterly Journal of Economics, 1991, 106(2), pp. 369-405. 

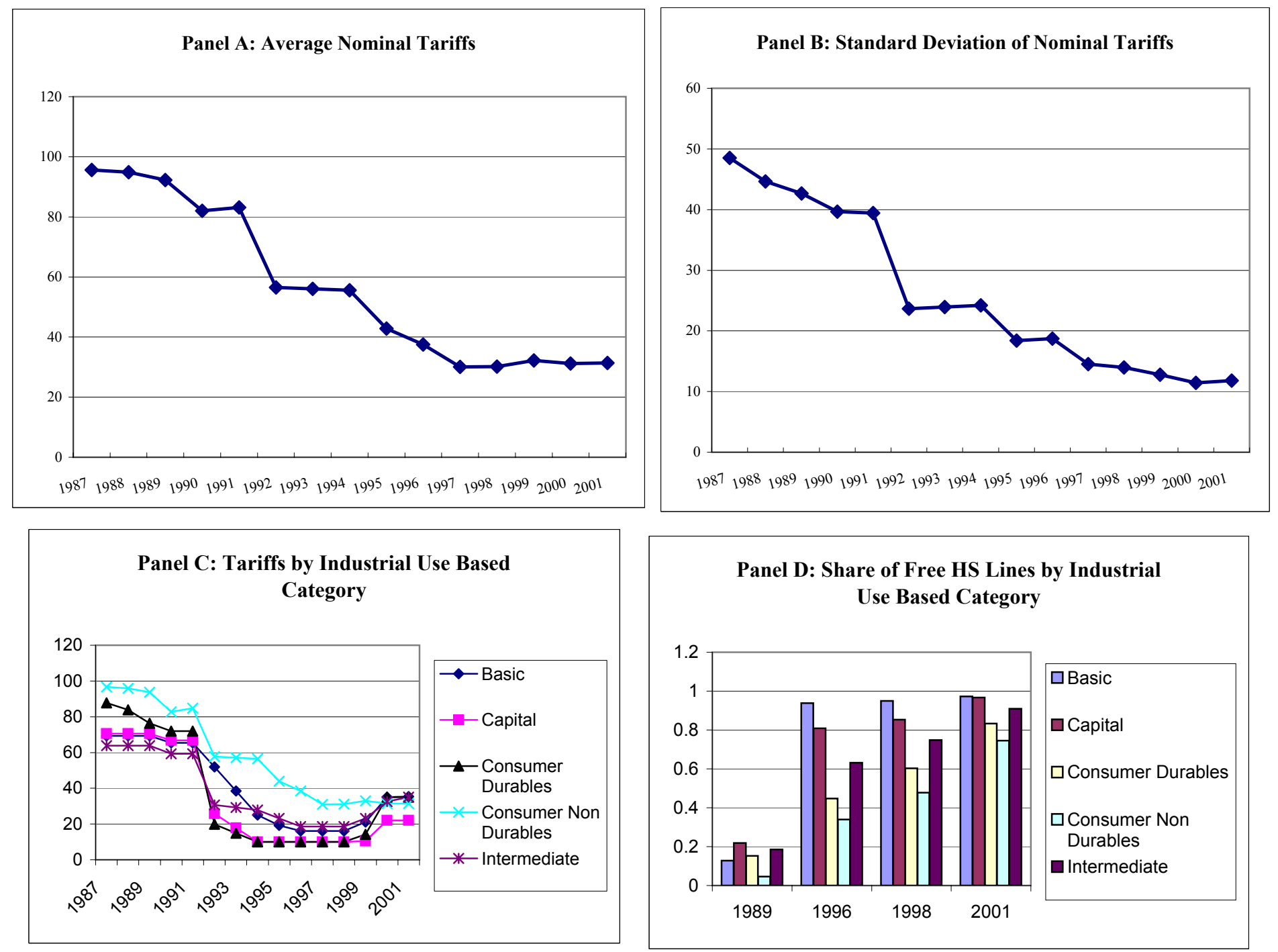

Panel E: Correlation of Industry Tariffs in 1997 and 1987

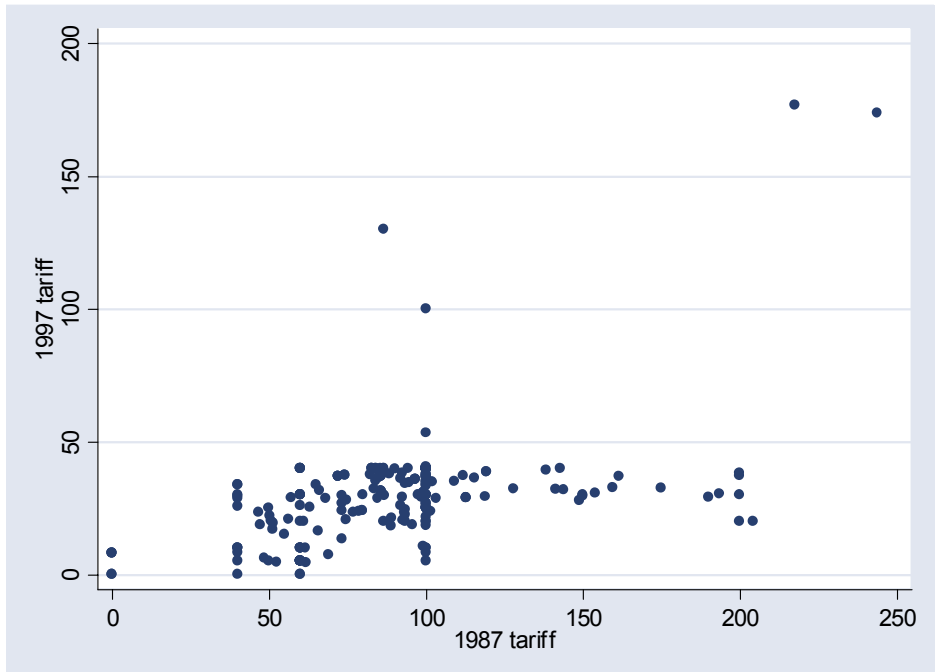

Panel F: Tariff Decline and Industry Tariffs in 1987

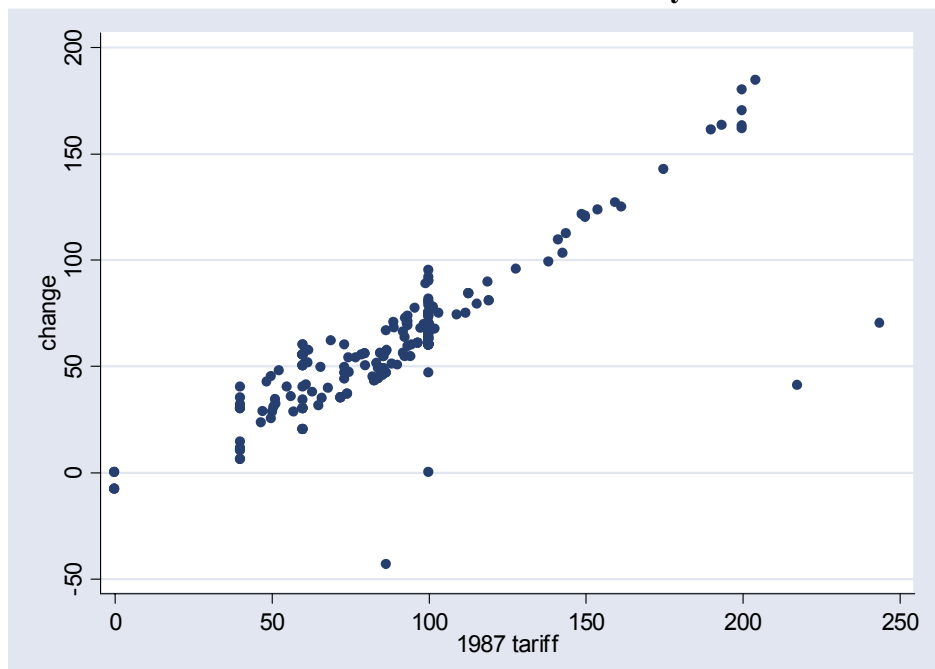

All figures from Topalova (2005). 
Figure 2. Evolution of India's Trade
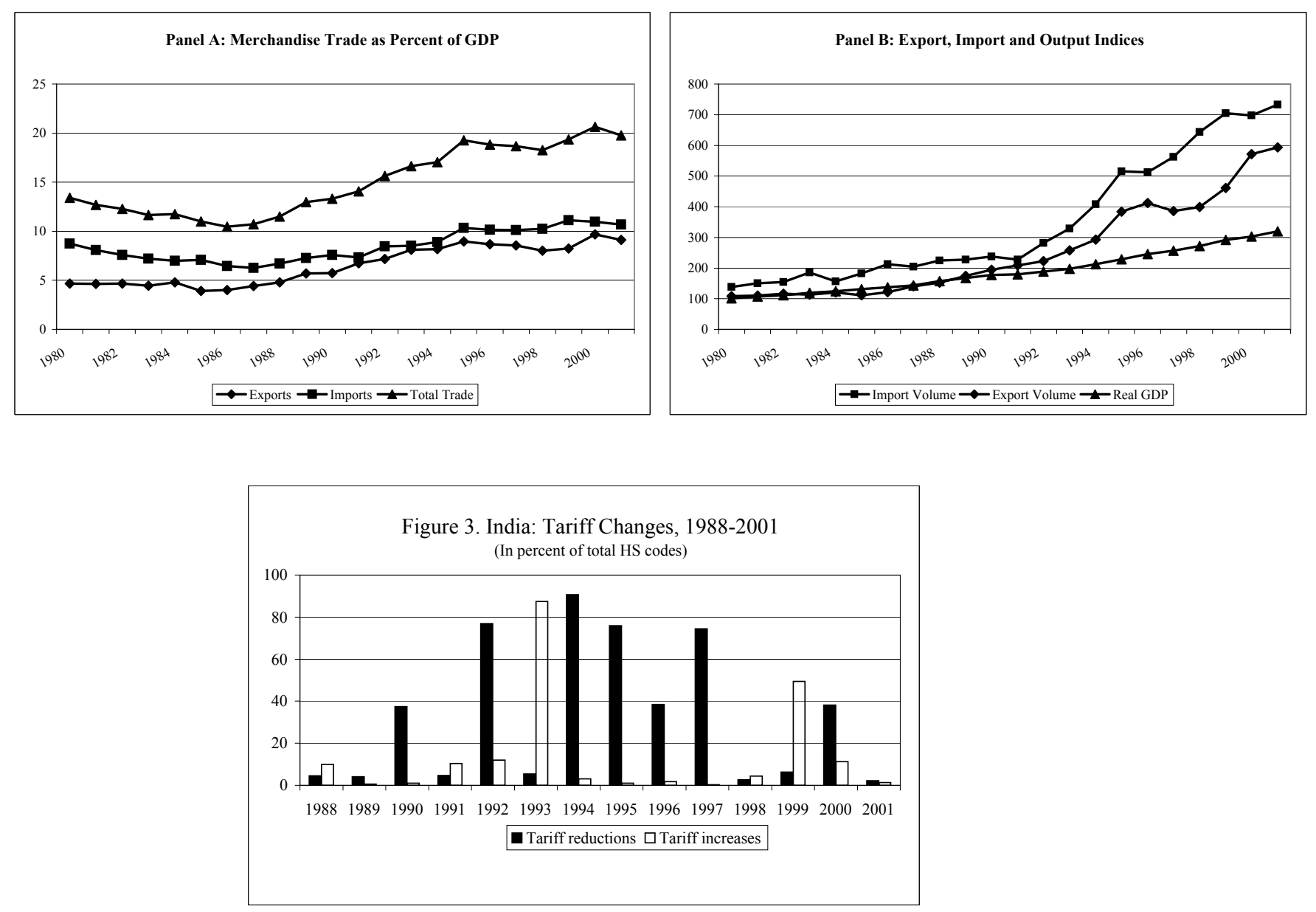

All figures from Topalova (2005). 


\begin{tabular}{|c|c|c|c|c|c|c|c|c|}
\hline & (1) & (2) & (3) & (4) & $(5)$ & $(6)$ & $(7)$ & $(8)$ \\
\hline \multicolumn{9}{|c|}{ Panel A. Output Tariffs } \\
\hline Log Real Wage & $\begin{array}{r}0.049 \\
(0.069)\end{array}$ & & & & & & & \\
\hline Share of Non-production Workers & & $\begin{array}{r}0.300 \\
(0.425)\end{array}$ & & & & & & \\
\hline Capital Labor ratio & & & $\begin{array}{r}0.000 \\
(0.033)\end{array}$ & & & & & \\
\hline Log Output & & & & $\begin{array}{c}0.002 \\
0.035)\end{array}$ & & & & \\
\hline Factory size & & & & & $\begin{array}{r}0.000 \\
(0.000)\end{array}$ & & & \\
\hline Log Employment & & & & & & $\begin{array}{r}-0.028 \\
(0.024)\end{array}$ & & \\
\hline Growth Log Output 82-87 & & & & & & & $\begin{array}{r}-0.018 \\
(0.099)\end{array}$ & \\
\hline Growth Log Employment 82-87 & & & & & & & & $\begin{array}{r}0.093 \\
(0.130)\end{array}$ \\
\hline Number of Observations & 135 & 135 & 135 & 135 & 134 & 135 & 135 & 135 \\
\hline \multicolumn{9}{|c|}{ Panel B. Input Tariffs } \\
\hline Log Real Wage & $\begin{array}{l}0.098 \text { ** } \\
(0.043)\end{array}$ & & & & & & & \\
\hline Share of Non-production Workers & & $\begin{array}{r}0.558 \\
(0.341)\end{array}$ & & & & & & \\
\hline Capital Labor ratio & & & $\begin{array}{r}0.011 \\
(0.019)\end{array}$ & & & & & \\
\hline Log Output & & & & $\begin{array}{l}-0.006 \\
0.010)\end{array}$ & & & & \\
\hline Factory size & & & & & $\begin{array}{r}0.000 \\
(0.000)\end{array}$ & & & \\
\hline Log Employment & & & & & & $\begin{array}{r}-0.032 \\
(0.020)\end{array}$ & & \\
\hline Growth Log Output 82-87 & & & & & & & $\begin{array}{r}0.007 \\
(0.028)\end{array}$ & \\
\hline Growth Log Employment 82-87 & & & & & & & & $\begin{array}{r}-0.018 \\
(0.051)\end{array}$ \\
\hline Number of Observations & 131 & 131 & 131 & 131 & 130 & 131 & 131 & 131 \\
\hline \multicolumn{9}{|c|}{ Panel C. Effective Rates of Protection } \\
\hline Log Real Wage & $\begin{array}{r}0.039 \\
(0.130)\end{array}$ & & & & & & & \\
\hline Share of Non-production Workers & & $\begin{array}{r}0.348 \\
(0.864)\end{array}$ & & & & & & \\
\hline Capital Labor ratio & & & $\begin{array}{r}-0.006 \\
(0.059)\end{array}$ & & & & & \\
\hline Log Output & & & & $\begin{array}{c}0.018 \\
0.060)\end{array}$ & & & & \\
\hline Factory size & & & & & $\begin{array}{r}0.000 \\
(0.000)\end{array}$ & & & \\
\hline Log Employment & & & & & & $\begin{array}{r}-0.031 \\
(0.046)\end{array}$ & & \\
\hline Growth Log Output 82-87 & & & & & & & $\begin{array}{r}-0.064 \\
(0.162)\end{array}$ & \\
\hline Growth Log Employment 82-87 & & & & & & & & $\begin{array}{r}0.139 \\
(0.213)\end{array}$ \\
\hline Number of Observations & 129 & 129 & 129 & 129 & 128 & 129 & 129 & 129 \\
\hline
\end{tabular}

Note: Robust standard errors in parentheses. All regressions include indicators for industry use type: i.e. Capital Goods, Consumer Durables, Consumer Non-Durables and Intermediate. Regressions are weighted by the square root of the number of factories. Data are from the 1987 ASI and cover mining and manufacturing industries. Significance at the 10 percent level of confidence is represented by a $*$, at the 5 percent level by a**, and at the 1 precent level by $* * *$. 


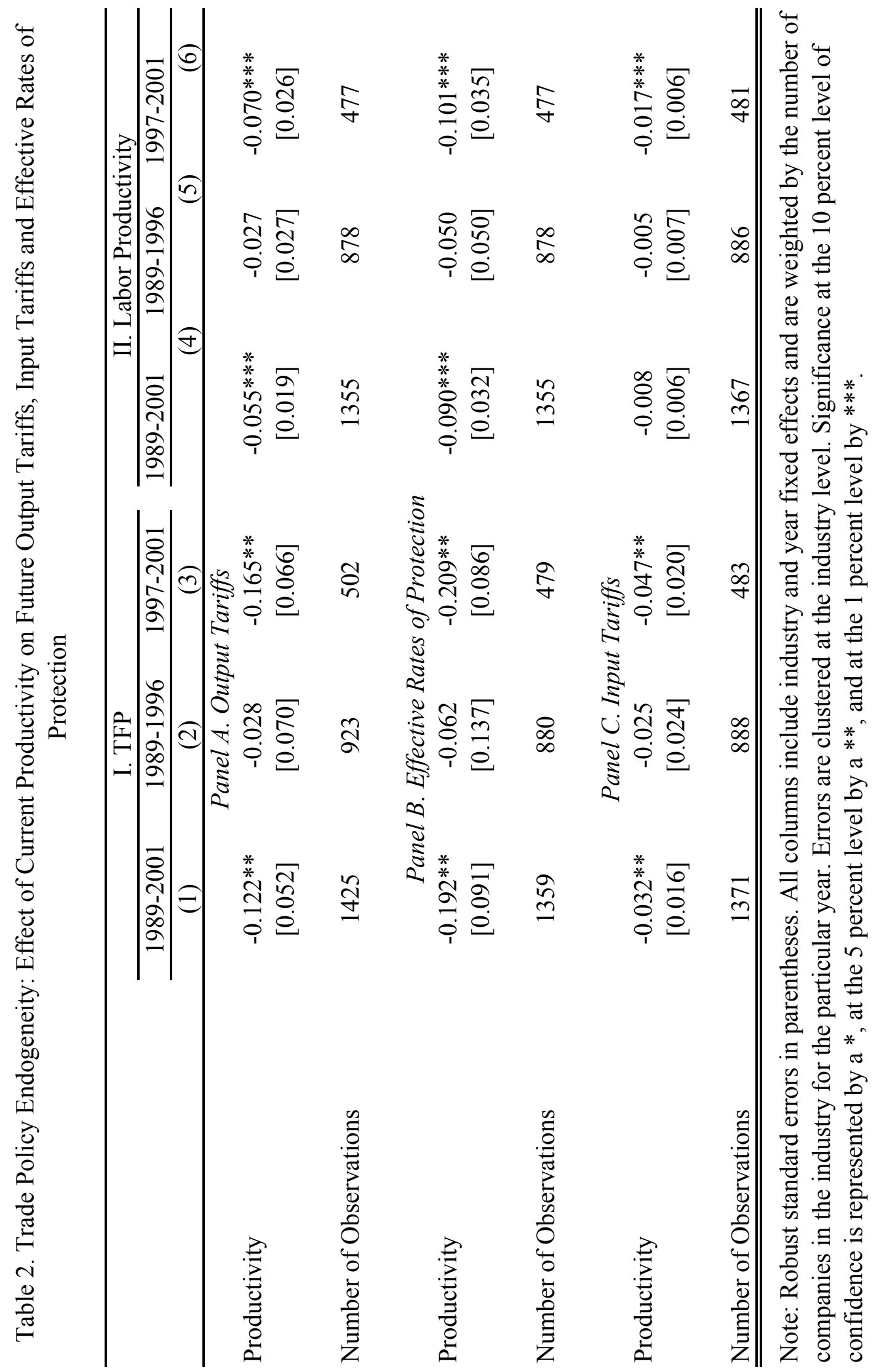




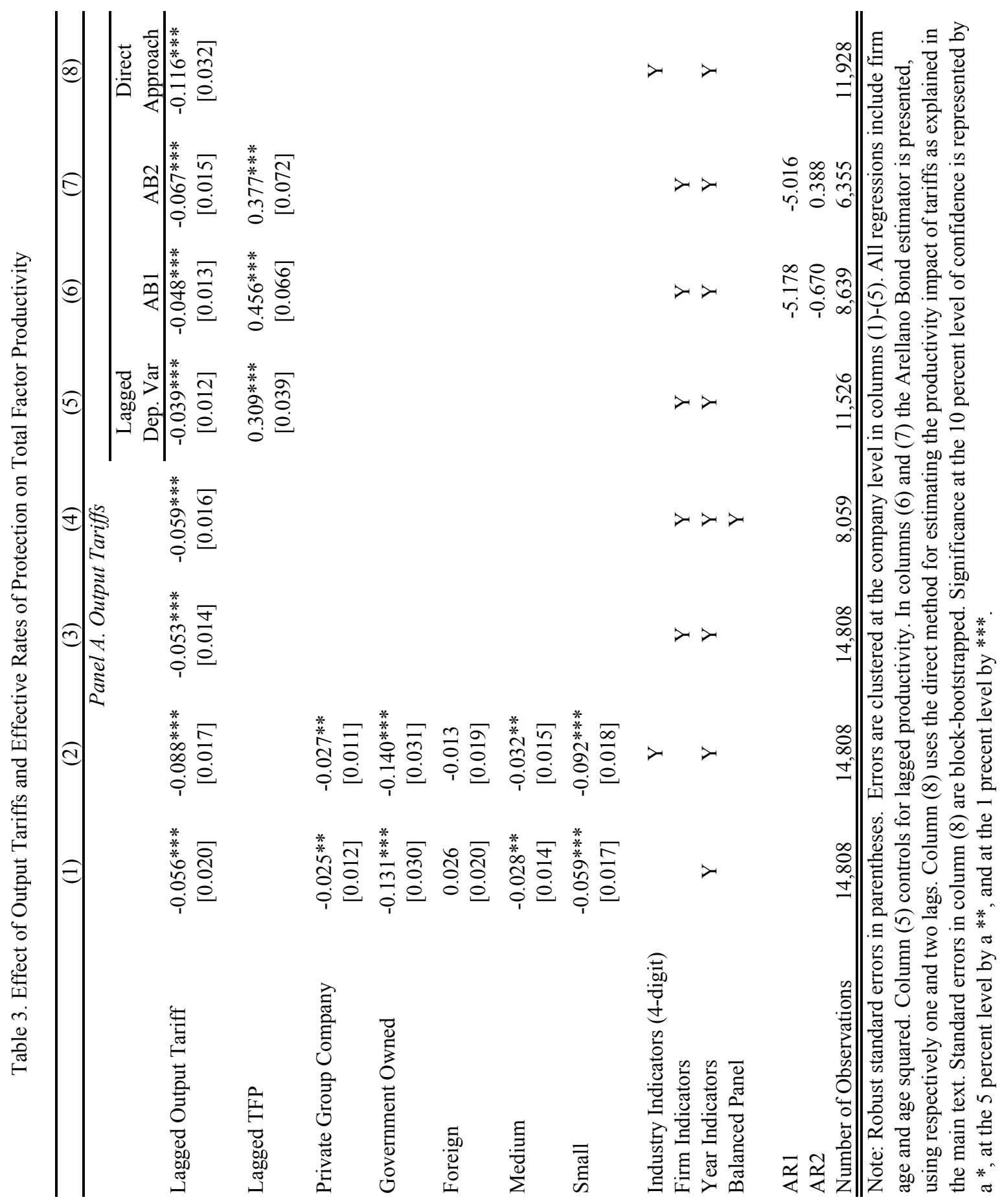




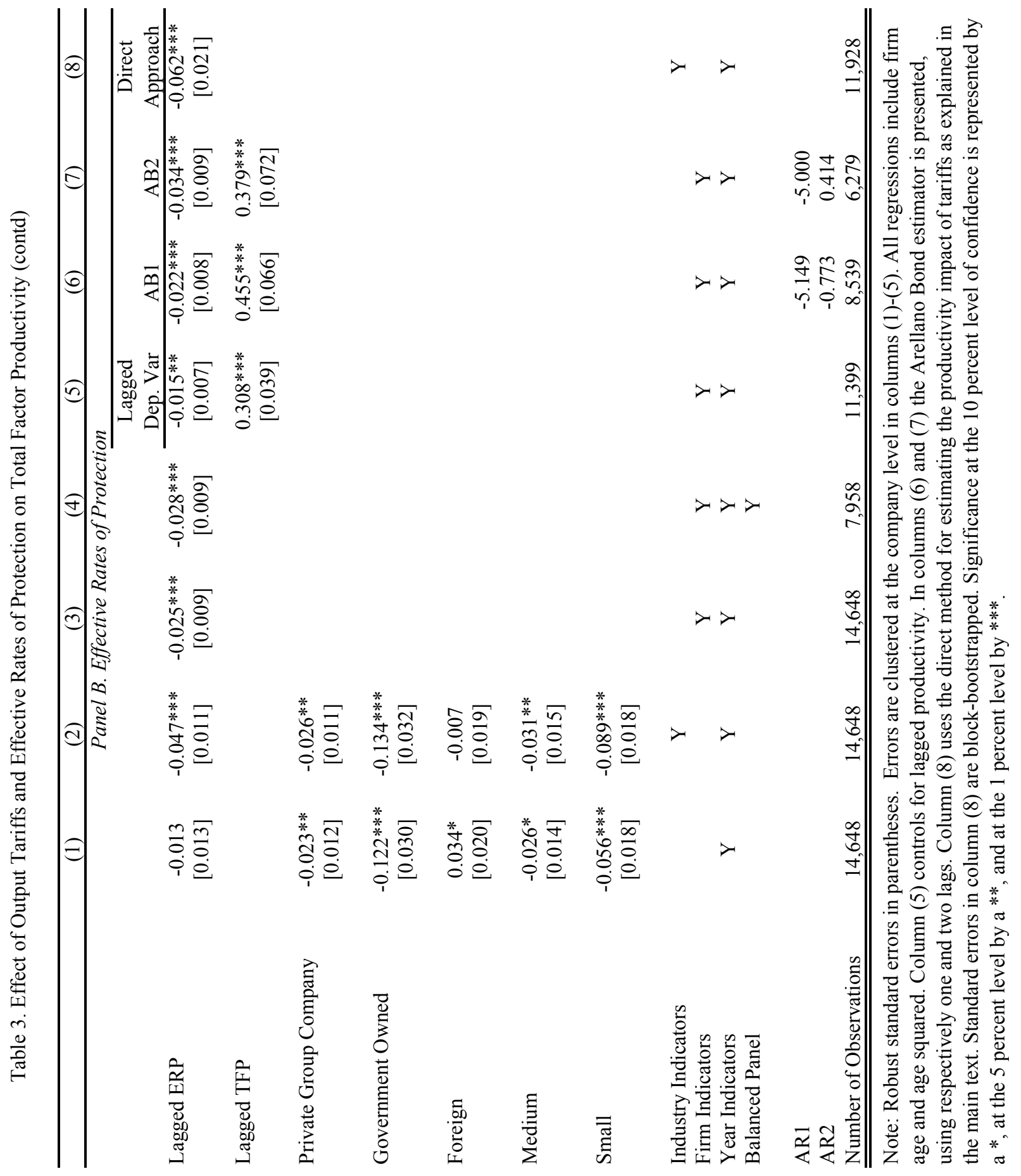




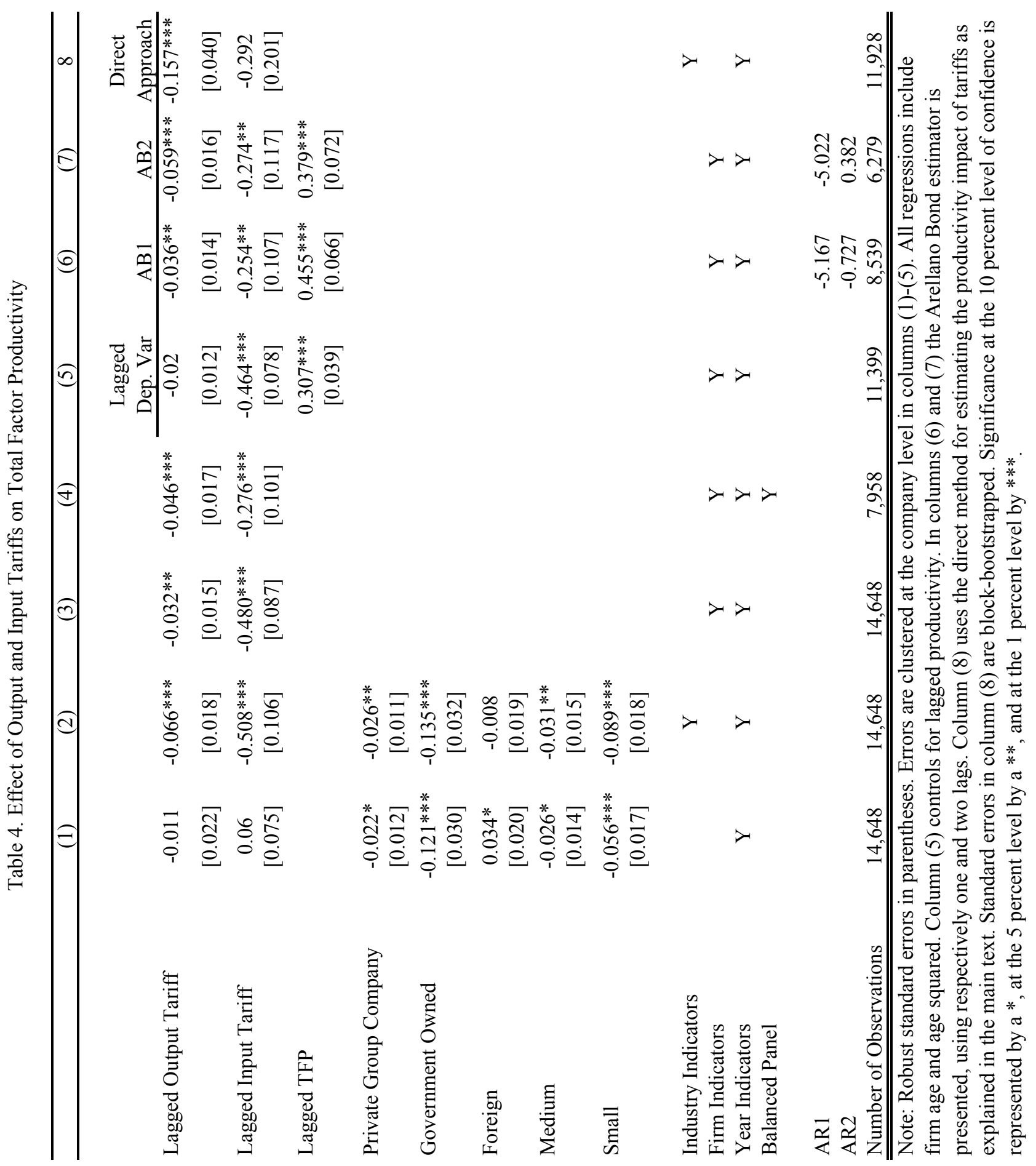




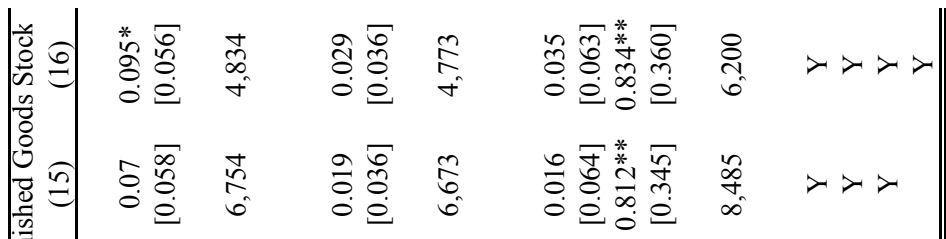

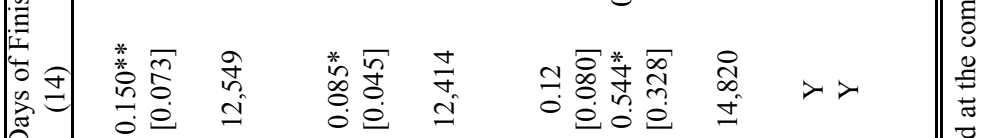

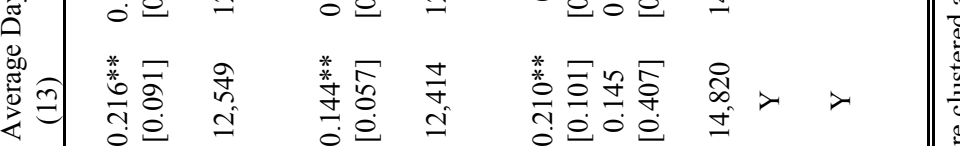

ป

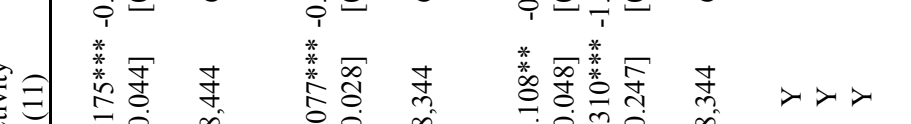

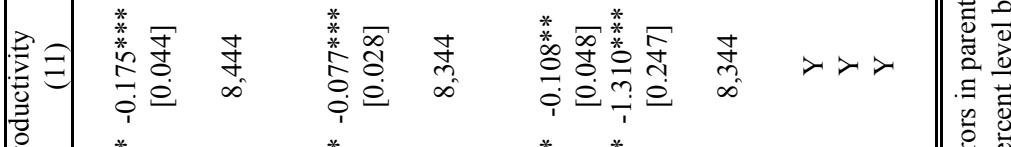

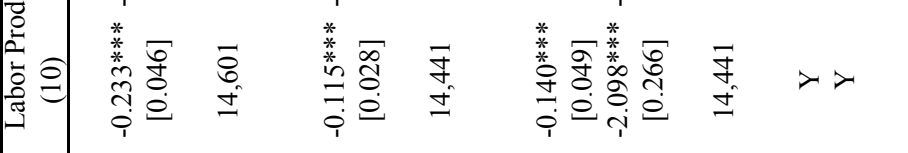

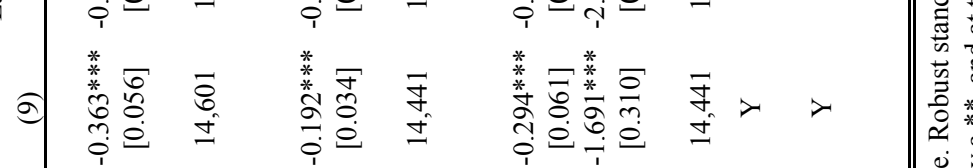

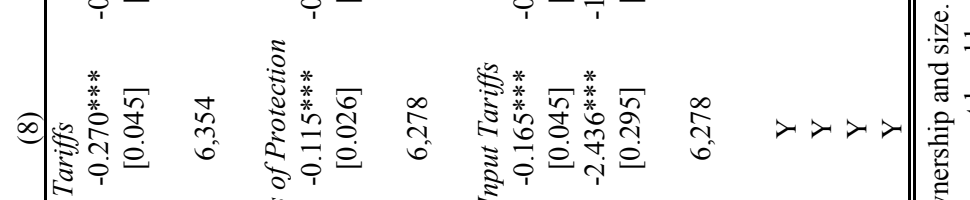

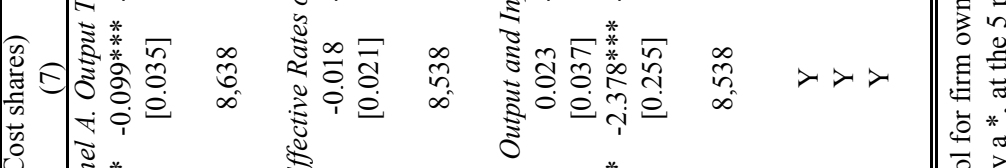

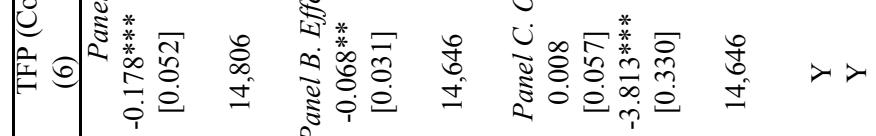

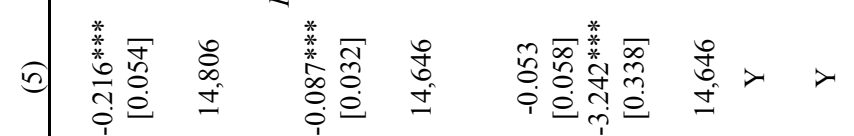

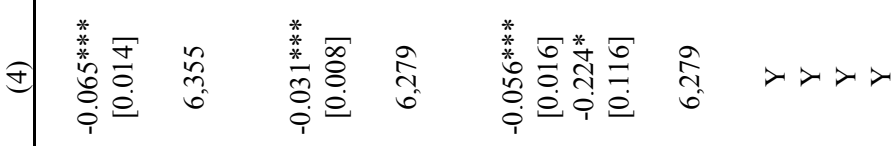

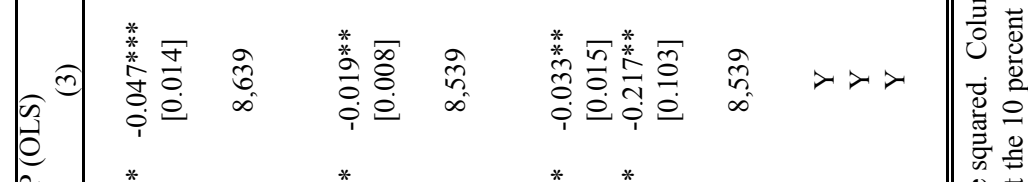

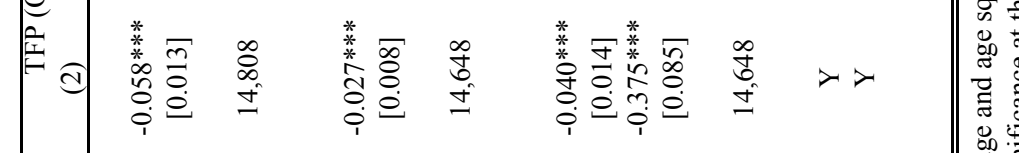

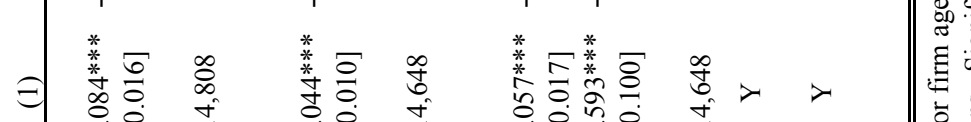

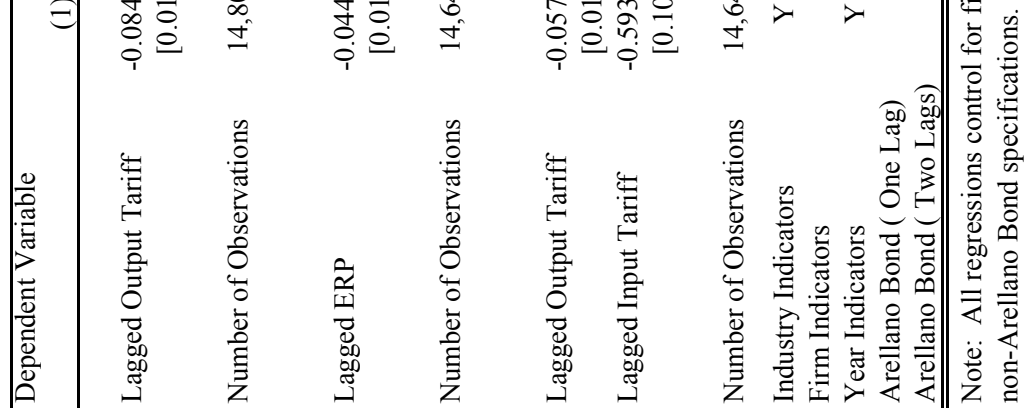




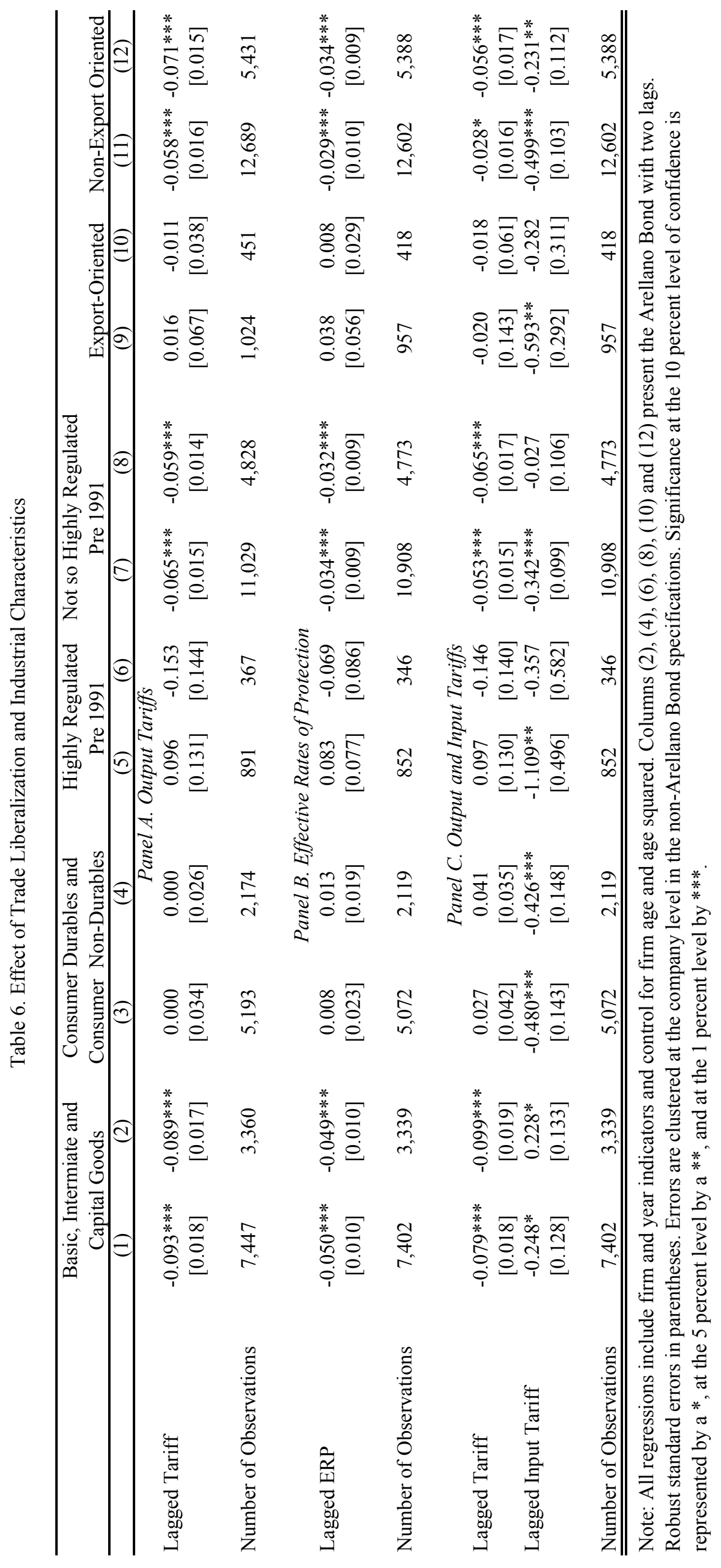




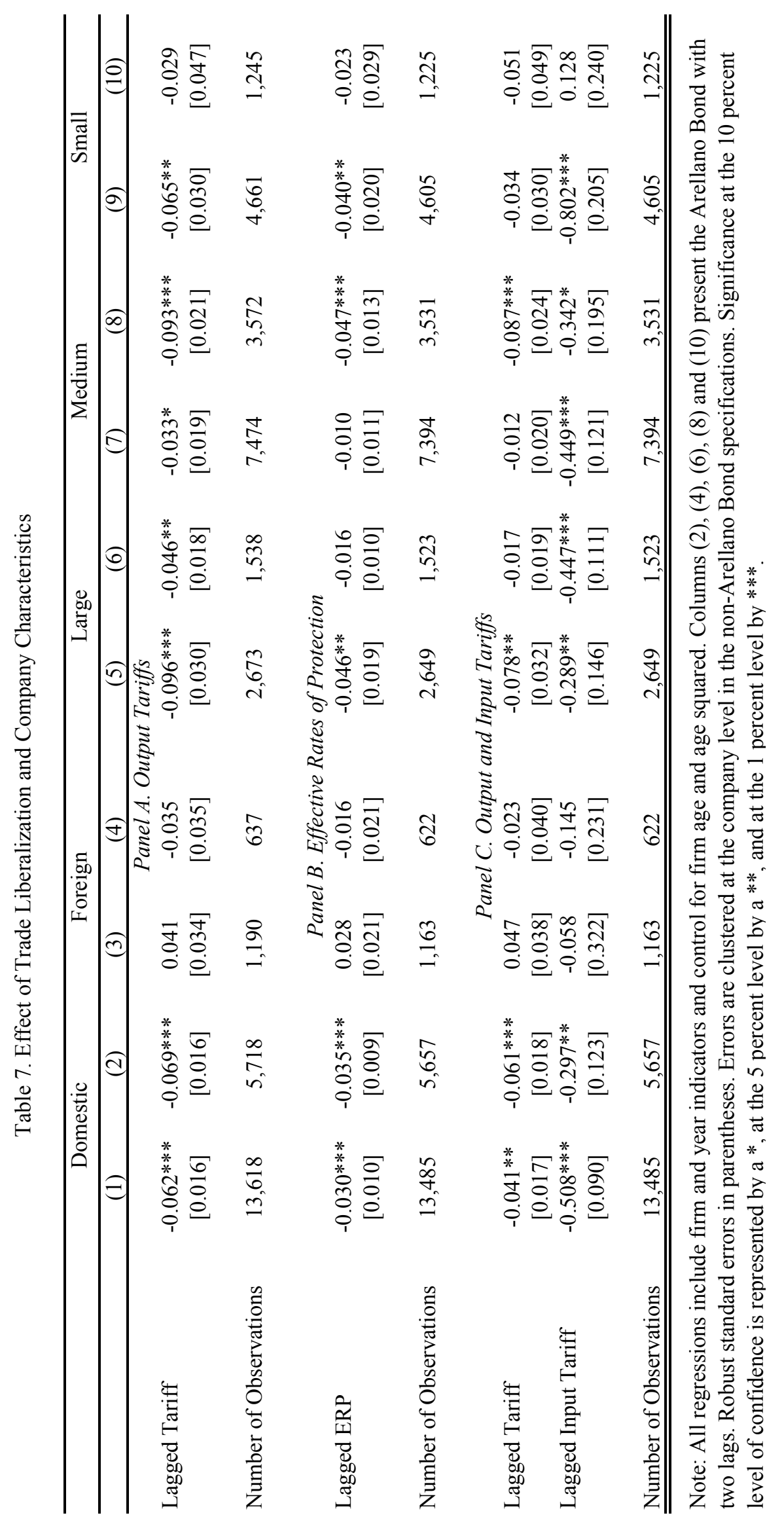




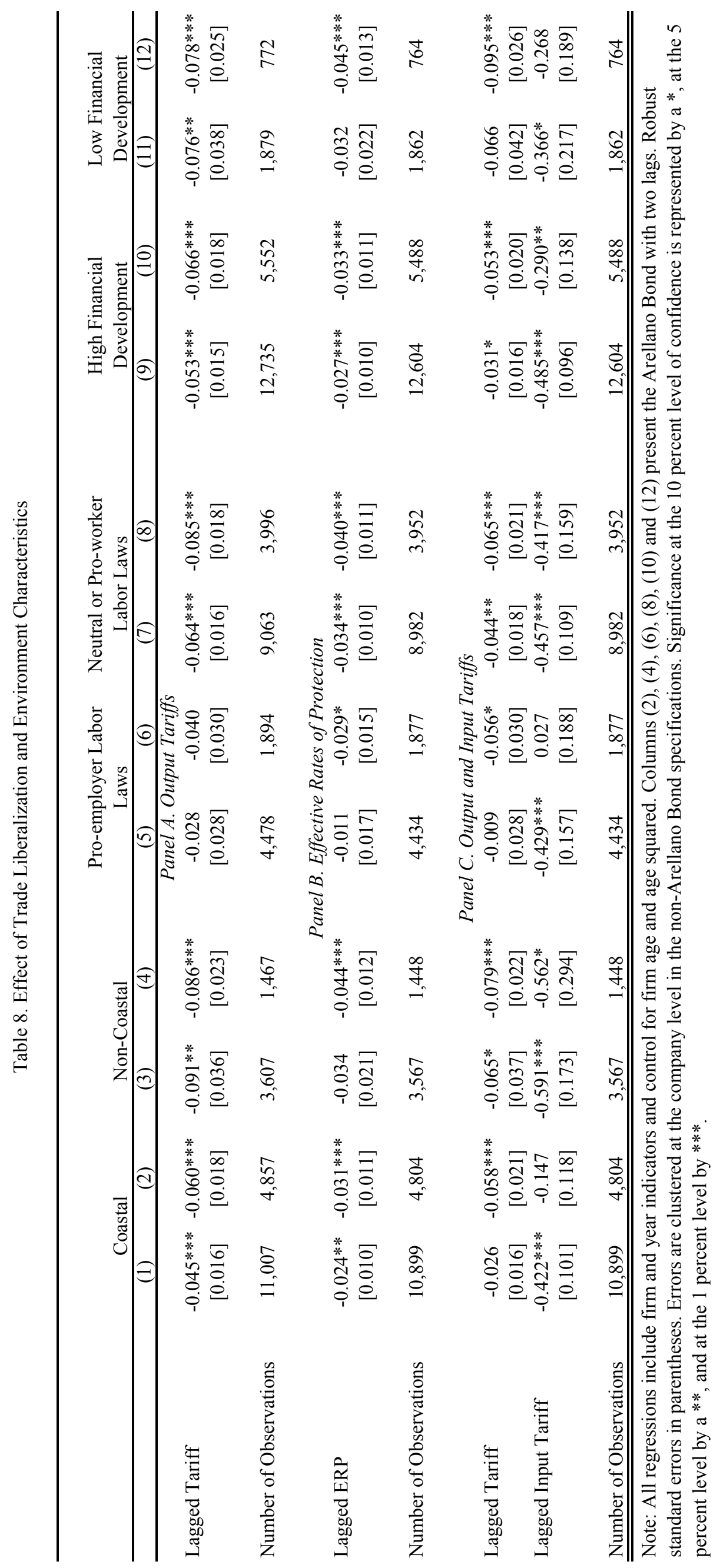




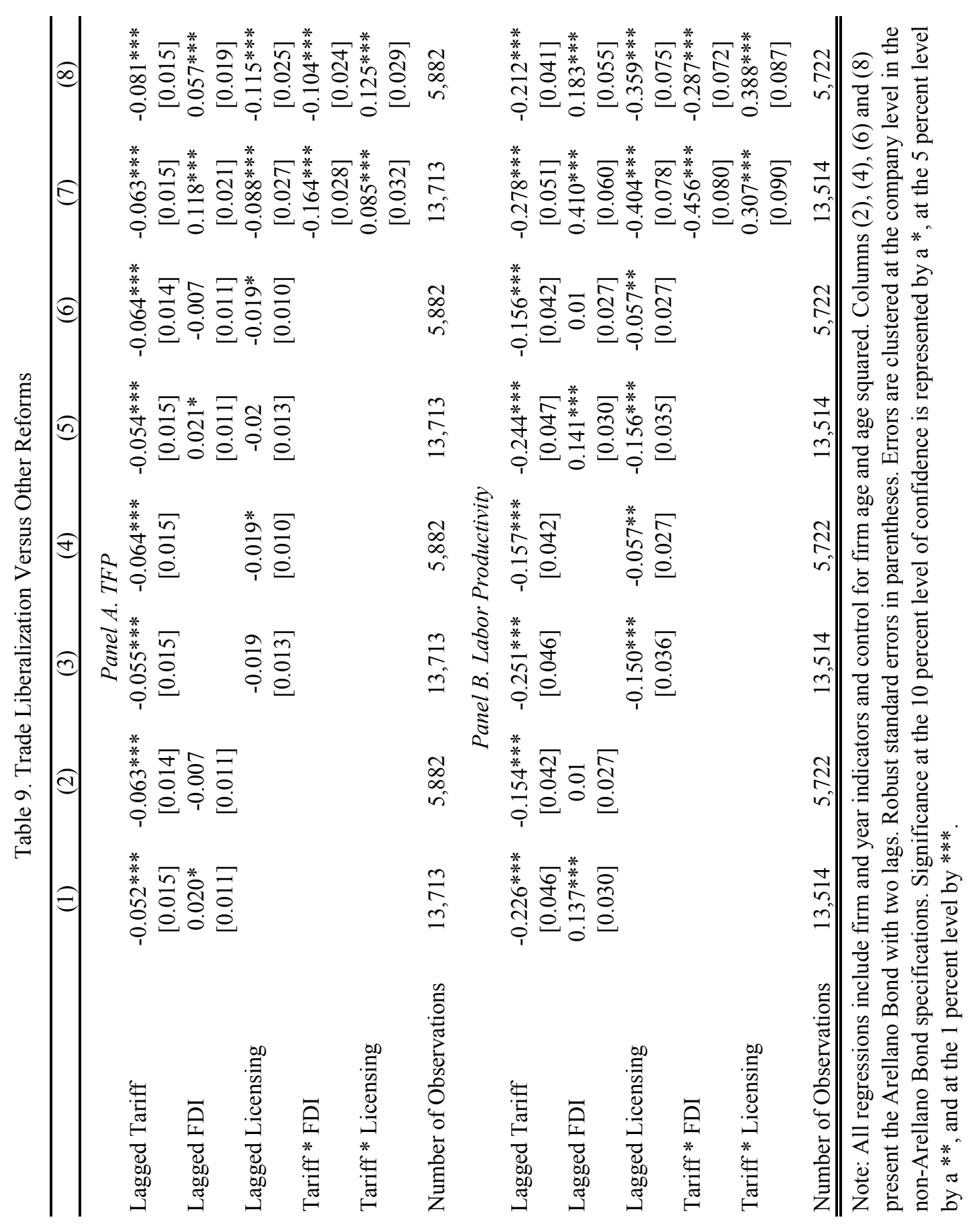


Table A1. Evolution of India's Output Tariffs, Effective Rates of Protection and Input Tariffs

\begin{tabular}{ccccccc}
\hline \hline & & StDev & & \multicolumn{2}{c}{ StDev Input } \\
Year & Output Tariff & Tariff & ERP & StDev ERP & InputTariff & $\begin{array}{c}\text { Tariff } \\
1989\end{array}$ \\
\hline 1990 & 0.96 & 0.29 & 0.99 & 0.43 & 0.36 & 0.09 \\
1991 & 0.81 & 0.25 & 0.83 & 0.37 & 0.30 & 0.07 \\
1992 & 0.87 & 0.30 & 0.92 & 0.42 & 0.30 & 0.07 \\
1993 & 0.61 & 0.20 & 0.62 & 0.15 & 0.22 & 0.05 \\
1994 & 0.81 & 0.22 & 0.81 & 0.16 & 0.31 & 0.07 \\
1995 & 0.60 & 0.22 & 0.61 & 0.15 & 0.22 & 0.05 \\
1996 & 0.46 & 0.14 & 0.47 & 0.13 & 0.17 & 0.04 \\
1997 & 0.39 & 0.14 & 0.40 & 0.16 & 0.14 & 0.03 \\
1998 & 0.32 & 0.14 & 0.33 & 0.12 & 0.11 & 0.03 \\
1999 & 0.32 & 0.13 & 0.34 & 0.11 & 0.11 & 0.03 \\
2000 & 0.34 & 0.11 & 0.35 & 0.10 & 0.12 & 0.03 \\
2001 & 0.33 & 0.11 & 0.33 & 0.11 & 0.12 & 0.03 \\
$1989-1996$ & 0.33 & 0.12 & 0.33 & 0.11 & 0.12 & 0.03 \\
\hline
\end{tabular}

Table A2. Distribution of Companies by Year

\begin{tabular}{|c|c|c|c|}
\hline Year & $\begin{array}{l}\text { Number of } \\
\text { Companies } \\
\text { in Dataset }\end{array}$ & $\begin{array}{l}\text { Number of } \\
\text { Companies } \\
\text { that survive } \\
\text { until } 1996\end{array}$ & $\begin{array}{c}\text { Number of } \\
\text { Companies that } \\
\text { survive until } \\
2001\end{array}$ \\
\hline 1989 & 936 & 813 & 652 \\
\hline 1990 & 1,120 & 1000 & 784 \\
\hline 1991 & 1,413 & 1235 & 944 \\
\hline 1992 & 1,574 & 1379 & 1,042 \\
\hline 1993 & 1,844 & 1639 & 1,187 \\
\hline 1994 & 2,315 & 2065 & 1,405 \\
\hline 1995 & 2,733 & 2501 & 1,613 \\
\hline 1996 & 2,954 & 2954 & 1,746 \\
\hline 1997 & 3,015 & - & 1,852 \\
\hline 1998 & 3,083 & - & 1,947 \\
\hline 1999 & 3,175 & - & 2,099 \\
\hline 2000 & 3,348 & - & 2,275 \\
\hline 2001 & 2,941 & - & 2,941 \\
\hline
\end{tabular}

Table A3. Descriptive Statistics

\begin{tabular}{lccc}
\hline \hline & Mean & StDev & Median \\
\hline Value of output & $1,401.81$ & $10,379.14$ & 270.52 \\
Gross Fixed Assest & $1,121.94$ & $6,814.55$ & 169.98 \\
Net Fixed Assets & 758.32 & $4,700.02$ & 112.02 \\
Revalued Gross Fixed Asset: & $1,867.41$ & $11,038.86$ & 278.10 \\
Salaries and Wages & 100.42 & 499.50 & 17.29 \\
Power and Fuel Expenses & 75.52 & 342.06 & 9.22 \\
Raw Material Expenses & 822.71 & $8,239.87$ & 150.28 \\
& & & \\
Number of Observations & 32,422 & & \\
\hline
\end{tabular}

Note: The quantities are in millions of 1993/94 Indian Rupees. 


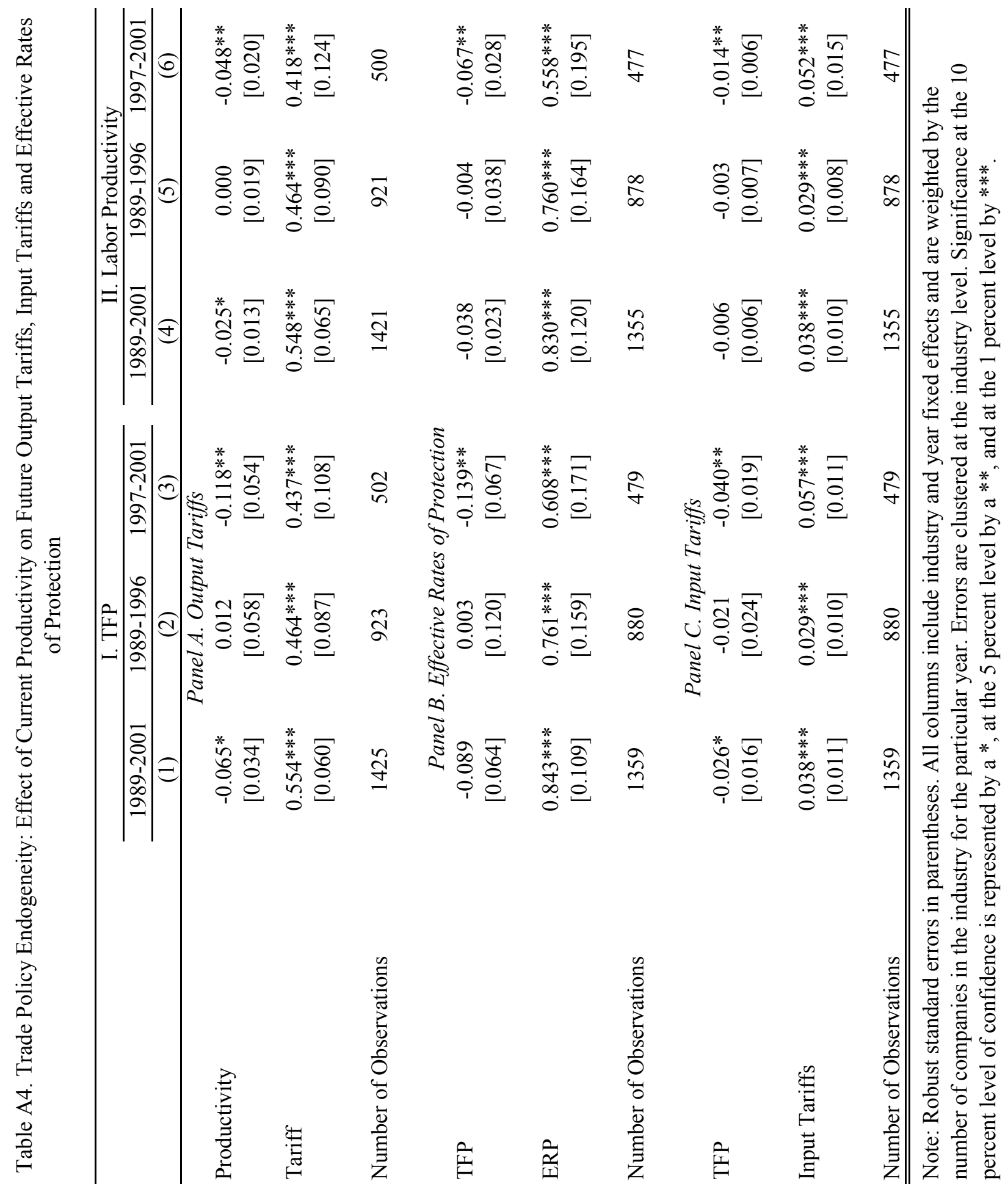




\section{Table A5. State Classifications}

$\begin{array}{ll}\text { Geographical classification } & \\ \text { Coastal State } & \text { Land Locked States } \\ \text { Andhra Pradhesh } & \text { Assam } \\ \text { Daman and Diu } & \text { Bihar } \\ \text { Dadra and Nagar Haveli } & \text { Chandigarh } \\ \text { Goa } & \text { Chattisgarh } \\ \text { Gujarat } & \text { Delhi } \\ \text { Karnataka } & \text { Haryana } \\ \text { Kerala } & \text { Himachal Pradesh } \\ \text { Maharashtra } & \text { Jammu and Kashmir } \\ \text { Orissa } & \text { Jharkhand } \\ \text { Pondicherry } & \text { Madhya Pradesh } \\ \text { Tamil Nadu } & \text { Nagaland } \\ \text { West Bengal } & \text { Punjab } \\ & \text { Rajasthan } \\ & \text { Uttar Pradesh }\end{array}$

Labor laws (Besley and Burgess, 2002)

$\begin{array}{ll}\text { Employer Friendly } & \text { Worker Friendly } \\ \text { Andhra Pradhesh } & \text { Gujarat } \\ \text { Karnataka } & \text { Maharashtra } \\ \text { Kerala } & \text { Orissa } \\ \text { Madhya Pradesh } & \text { West Bengal } \\ \text { Rajasthan } & \\ \text { Tamil Nadu } & \end{array}$

Neutral

Assam

Bihar

Haryana

Punjab

Uttar Pradesh

Jammu and Kashmir

Financial Development (credit per capita, Reserve Bank of India)

Above median
Andhra Pradesh
Chandigarh
Daman \& Diu
Delhi
Goa
Gujarat
Haryana
Himachal Pradesh
Jammu \& Kashmir
Karnataka
Kerala
Maharashtra
Pondicherry
Punjab
Tamil Nadu
West Bengal

Below median

Andaman \& Nicobar Islands

Arunachal Pradesh

Assam

Bihar

Dadra \& Nagar Haveli

Lakshadweep

Madhya Pradesh

Manipur

Meghalaya

Mizoram

Nagaland

Orissa

Rajasthan

Sikkim

Tripura

Uttar Pradesh 